\title{
درجة استخدام معلمي المرحلة الأساسية العليا لأساليب تنمية التفكير الإبداعي من وجهة نظر الطلبة في المدارس الحكومية في محافظة طولكرم
}

\author{
زياد بركات \\ أستاذ العلم النفس التربوي، كلية التربية، جامعة القدس المفتوحة، فرع طولكرم \\ zbarakat@qou.edu
}

الملخص:

تهدف هذه الدراسة تقصي فعالية استخدام معلمي المرحلة الأساسية العليا لأساليب تتمية التفكير الإبداعي من وجهة نظر الطلبة في المدارس الحكومية بمحافظة طولكرم في فلسطين، ولتحقيق أغراض الدراسة تم تصميم استبانة لقياس فعالية المعلم لاستخدام أساليب في تتمية التفكير الإبداعي للى الطلبة ومكونة من (•r) فقرة، تشير كل منها إلى أسلوب معين من أساليب تتمية التفكير الإبداعي، وبعد التحقق من الصدق والثبات لهذه الاستبانة تم تطبيقها على عينة من طلبة المرحلة الأساسية العليا من

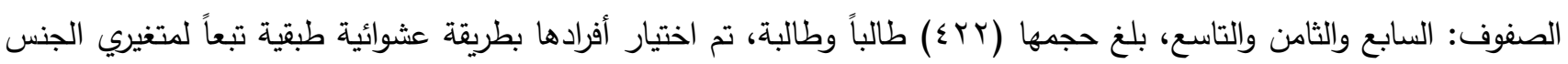
والصف، وقد أظهرت الدراسة النتائج الآتية: ا. كانت تقديرات الطلبة لاستخدام معلمي المرحلة الأساسية العليا لأساليب تتمية التفكير الإبداعي في المدارس الحكومية بمحافظة طولكرم بمستوى مرتفع بصفة عامة إذ بلغ المتوسط الحسابي لها ( VT . r).

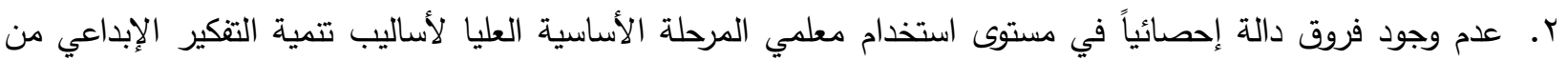
وجهة نظر الطلبة في المدارس الحكومية بمحافظة طولكرم تبعاً للمتغيرات: الجنس، والتحصيل الدراسي، والصف، ومكان الصان السكن. وفي ضوء نتائج الدراسة ومناقشتها اقترحت عدة توصيات كان أهمها: توفير برامج تدريبية للمعلمين تساعدهم على تبني

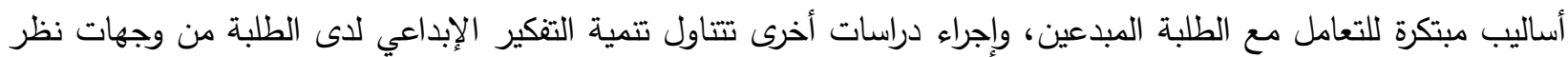
مختلفة لتعميق النتائج.

الكلمات المفتاحية: التفكير الابداعي، معلمي المرحلة الاساسية العليا (c) $(1)$

المقدمة:

يُعد التفكير الإبداعي من أهم القدرات التي يجب على الأنظمة التربوية توجيه عناية خاصة بها لكي تجيد هذه الأنظمة أداء

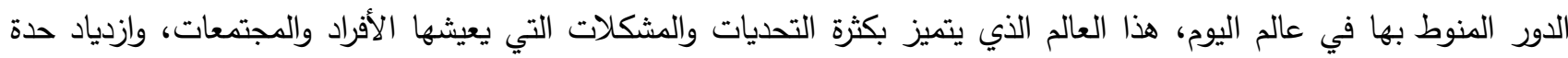
التنافس والصراع من أجل البقاء واثبات الوجود، إن معظم الإنجازات العلمية والتكنولوجية التي حققتها البشرية في القرن العشرين هي نتاجات أفكار المبدعين، ولكن العلم في الماضي كان يصمم لعالم مستقر أما الآن فإن مجتمعنا يعيش في عالم سريع التغير تحيطه 
تحديات محلية وعالمية لعل أهمها الانفجار المعرفي والتطور التكنولوجي والانفتاح على العالم نتيجة سرعة الاتصالات والمواصلات حتى أصبح العالم قرية صغيرة، كل ذلك يحتاج منا السرعة في تتمية عقليات قادرة على حل المشكلات.

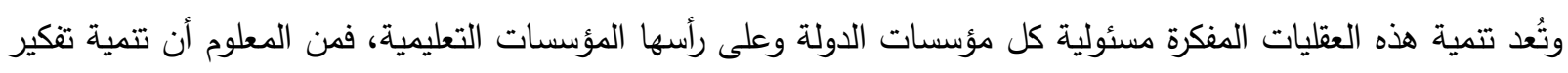
الفرد يمكن أن تتم من خلال المناهج الدراسية المختلفة داخل المؤسسات التعليمية، والمناهج باختلافها تساهم في تتمية التفكير والقدرة على حل المشكلات لدى الطلبة وتسهم في زيادة قدراتهم في أنواع التفكير المختلفة إذا توفر لتدريسها الإمكانات اللازمة باتهات

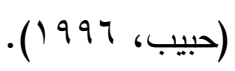

إن القدرات الإبداعية موجودة عند كل الأفراد بنسب متفاوتة، وهي بحاجة إلى الإيقاظ والتدريب لكي تتوقد، وإن النمطية في الأساليب التعليمية توقف أو تعيق تلك القدرات ولا تؤدي إلى إعداد أفراد يمتازون بالفكر قادرين وهين على الإنى الإنتاج المتنوع والجديد، والذي وإني تحتاجه التتمية الثاملة للمجتمع في القرن الحادي والعشرين، فاليوم بحاجة أكثر من قبل إلى إستراتيجيات تعليم وتعلم تمد الفرد بآفاق تعليمية واسعة ومتتوعة ومتقدمة تساعد الطلبة على إثراء معلوماتهم وتتمية مهارتهم العقلية المختلفة وتدربهم على الإبداع

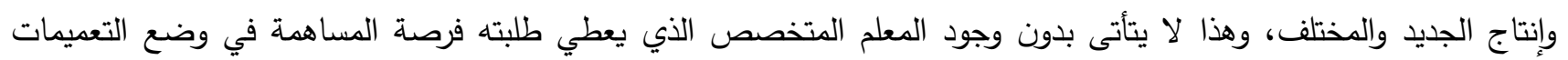

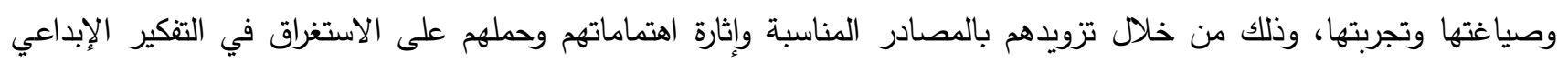

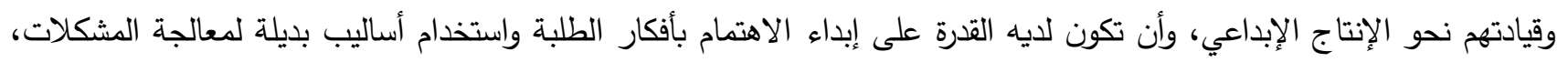
وعرض خطوات التفكير عند معالجة المشكلة بدلا من عرض النتيجة فقط، مما يدفعهم نحو تطوير نماذج التفكير والقدرة على تقييم

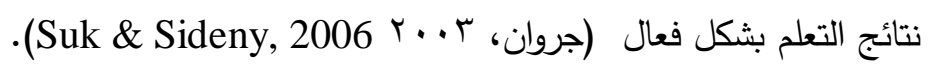

ويعتبر الإبداع والتنكير الإبداعي من أهم الأهداف التربوية، حيث أن تربية وتعليم الطلبة المبدعين في الدول المتقدمة كان من العوامل الأساسية التي أدت إلى التقدم العلمي والاقتصادي في العصر الحديث الإبث (سعادة ،2003). وتحديد المفهوم الدقيق للإبداع يساعد المعلمين التعرف إلى الطلبة المبدعين، أو ذوي القدرات والاتجاهات الإبداعية، ومن خلال مراجعة البحوث والدراسات التربوية

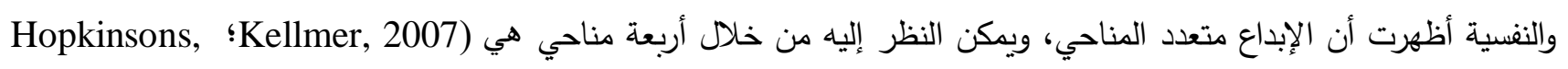

ا. ـ مفهوم الثخص بناء على سمات الثخص المبدع هو المبادأة التي يبديها المتعلم في قدرته على التخلص من السياق العادي

للتنكير وإتباع نمط جديد من التفكير .

r. مفهوم الإبداع على أساس الإنتاج قدرة المتعلم على الإنتاج إنتاجا يتميز بأكبر قدر من الطلاقة الفكرية والمرونة التلقائية

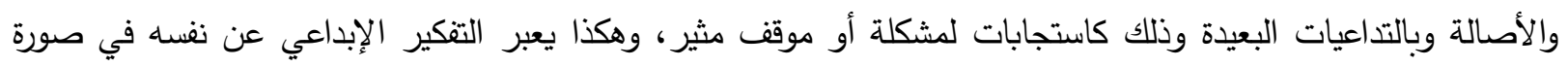
إنتاج شئ جديد، أو التفكير المغامر ، أو الخروج عن المألوف، أو ميلاد شئ جديد سواء كان فكرة أو اكتشافا أو اختراعا

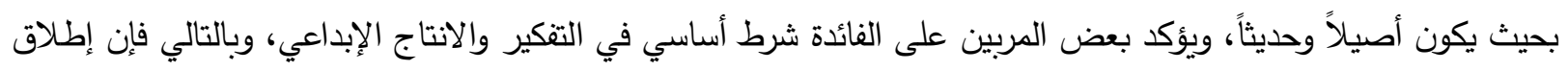
مفهوم الإبداع لا يجوز على إنتاج غير مفيد، أو إنتاج لا يحقق رضا مجموعة كبيرة من الناس في فترة معينة من الزمن. r. مفهوم الإبداع على أنه عملية الإبداع هو عملية يصبح فيها المتعلم حساسا للمشكلات، وبالتالي هو عملية إراك الثغرات

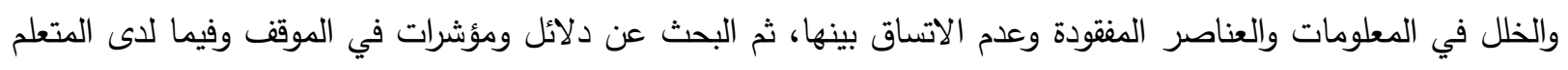
من معلومات، ووضع الفروض حولها، واختبار صحة هذه الفروض والربط بين النتائج، وربما إجراء التعديلات وإعادة اختبار الفروض. 


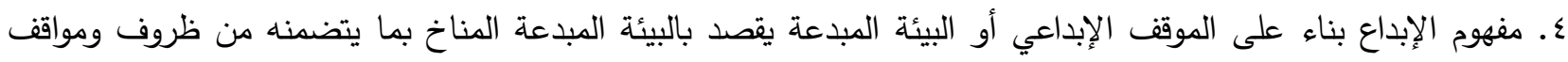

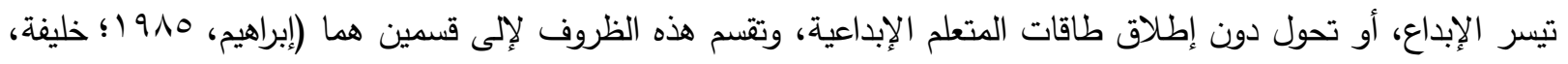

$$
:(r . .7
$$

أ. ظروف عامة: يرتبط بالمجتمع وثقافته، فالإبداع ينمو ويترعرع في المجتمعات التي تتميز بأنها تهيئ الفرص لأبنائها

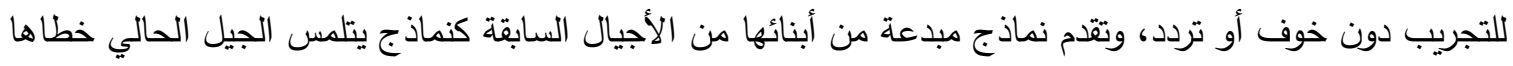

$$
\text { وبالتالي تشجع على نقد وتطوير الأفكار العلمية والرياضية والأدبية. }
$$

ب. ظروف خاصة: وترتبط بالمعلمين والمديرين والمشرفين التربويين وأدوارهم في تهيئة الظروف والبيئة الصفية والمدرسية

لتنمية الإبداع لدى الطلبة.

يتضمن الإبداع والتنكير الإبداعي مجموعة من القدرات العقلية تحددها غالبية البحوث والدراسات التربوية والنفسية بما يلي

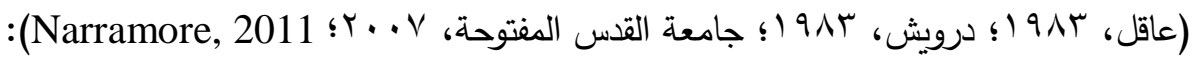

أولاً: الطلاقةة:

تتضمن الطلاقة الجانب الكمي في الإبداع، ويقصد بالطلاقة تعدد الأفكار التي يمكن أن يأتي بها المتعلم المبدع، وتتميز

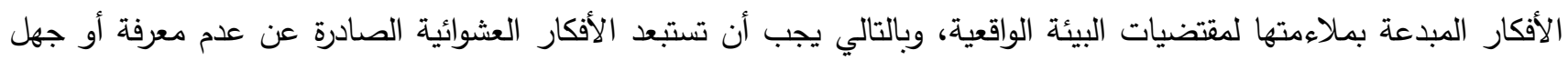

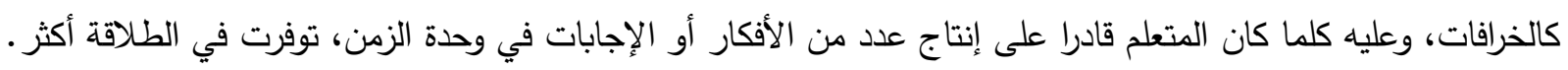
ثانياً: المرونة: تتضمن المرونة الجانب النوعي في الإبداع، ويقصد بالمرونة تتوع الأفكار التي يأتي بها المتعلم المبدع، وبالتالي تثير المرونة إلى درجة السهولة التي يغير بها المتعلم موقفا ما أو وجهة نظر عقلية معينة. ومن أشكال المرونة التكيفية، المرونة التلقائية، ومرونة إعادة التعريف أو التخلي عن مفهوم أو علاقة قديمة لمعالجة مشكلة جديدة، ومن الأمثلة عليها: اكتب مقالاً قصيراً لا يحتوي على أي فعل ماضي، فكر في جميع الطرق التي يمكن أن تصممها لوزن الأشياء الخفيفة جداً. فالتلميذ على سبيل المثال، الذي يقف عند فكرة معينة أو يتصلب فيها، يعتبر أقل قدرة على الإبداع من تلميذ مرن التفكير قادر على التغيير حين يكون ذلك ضرورياً.

ثالثاً: الأصالة: يقصد بالأصالة التجديد أو الإنفراد بالأفكار، كأن يأتي المتعلم بأفكار جديدة متجددة بالنسبة لأفكار زملائه، وعليه

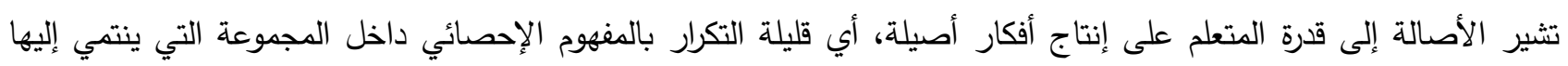

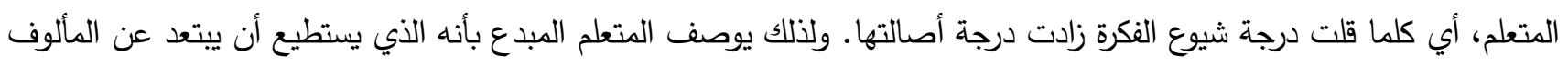

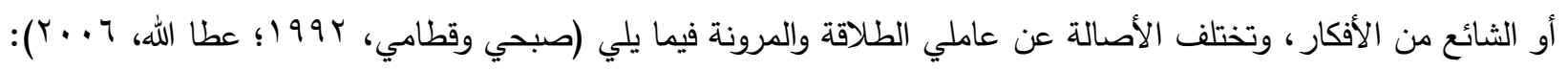
ا ـ الأصالة لا تشير إلى كمية الأفكار الإبداعية التي يعطيها الفرد ، بل تعتمد على قيمة ونوعية وجدة تلك الأفكار ، وهذا ما يميز الأصالة عن الطلاقة.

r. الأصالة لا تشير إلى نفور المتعلم من تكرار تصوراته أو أفكاره هو شخصيا كما في المرونة ، بل تشير إلى النفور من

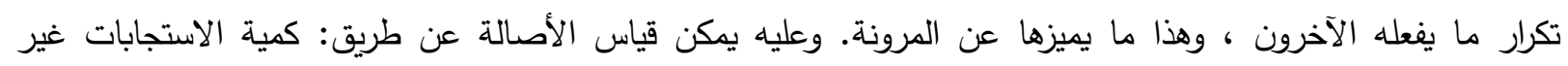

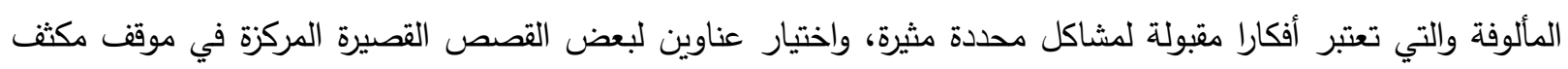

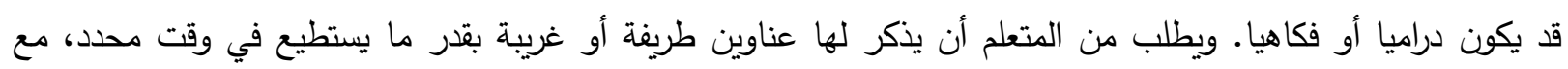
احتمال استبدال القصة بصورة أو شكل. 
رابعاً: التفاصيل (الإكمال): يقصد بالتفاصيل ( أو الإكمال أو التوسيع )البناء على أساس من المعلومات المعطاة لتكملة من نواحيه المختلفة حتى يصير أكثر تفصيلا أو العمل على امتداده في اتجاهات جديدة، أو هو قدرة المتعلم على تقديم إضافات

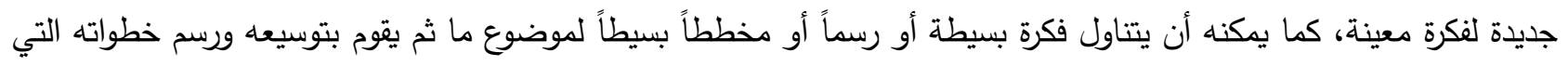

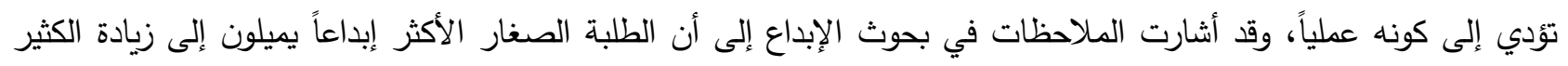

$$
\text { من التفاصيل غير الضرورية إلى رسوماتهم وقصصهم. }
$$

إن الإبداع كلمة محبوبة إلى معظم الناس، ويؤمنون إيماناً كاملاً بأهميتها، وأهمية تعلمها والعمل بها، بل وتصل الرغبة

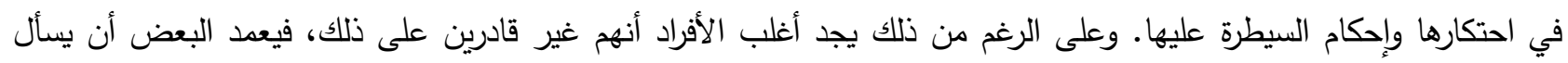

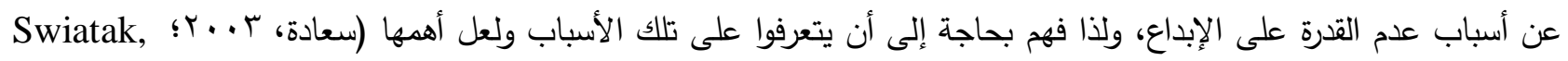

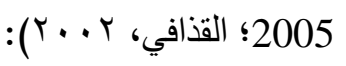

ا. حصر معنى أو تفسير لغوي واحد لمفهوم واحد: إن حصر المفاهيم ضمن معنى واحد يسبب محدودية لإدراكات

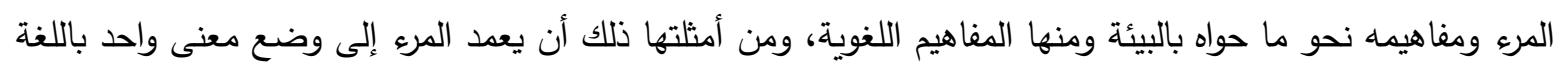

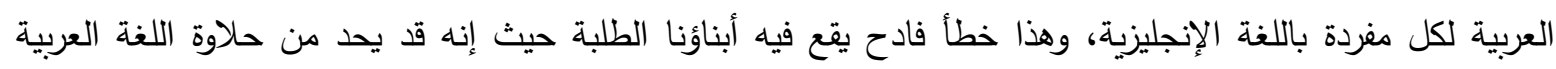
والأجنبية أيضا.

r. عدم القدرة على تشخيص المشكلة: يشكو معظم الناس من مشكلات تواجههم في الحياة، بيد أن معظمه لا يستطيع أن يشخص المشكلة الرئيسية من سمات المشكلة أو المواصفات الجانبية التابعة لها، كأن يشكو المتعلم من عدم معرفته لجدول الضرب وفي الحقيقة تكون المشكلة في عمليات الجمع. ب. محدودية الخبرة: إن محدودية خبرة المرء تجعله لا يرى المشكلة إلا من زاوية واحدة، وفي معظم الأحيان حسب ما تقع عليه عيناه فقط ، لذا قد يخطئ المرء في تقديراته.

ع. عدم استعمال الحواس "الخمس" بالطريقة السليمة: إن تعود المرء على السرعة في أمره لا تمنحه الوقت للتجريب واستخدام كافة الحواس الخمس لحل مشكلاته، فتكثر عمليات الغش والخداع ويقع المره فريسة لهذه العمليات. ه. التدريس التقليدي في مدارسنا والذي يتمثل في بعض جوانبه الطلب من الطلاب وبإصرار أن يجلسوا ملتزمين في مقاعدهم، و أن يمتصوا المعرفة الملقاة لهم كما يمتص الإسفنج الماء يعوق النشاط الإبداعي ونمو القدرات الإبداعية.

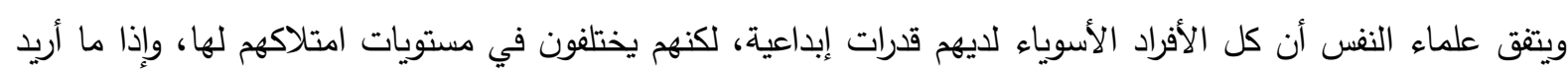

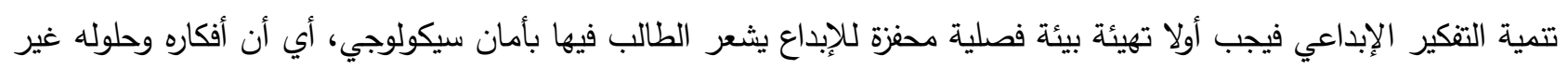
ههددة بالنقد والتهكم. كما يجب تقبل أسئلة الطلبة وتعزيزها، وعلى المعلم اتباع الإجراءات التالية (العيسوي، $:\left(r^{\prime} \cdot \boldsymbol{T}\right.$

العمل على إثارة الخيال الخصب عند الطلبة، وذلك بإبراز ظواهر وأحداث يمكن لدارس المرحلة الثانوية إثارة خيال

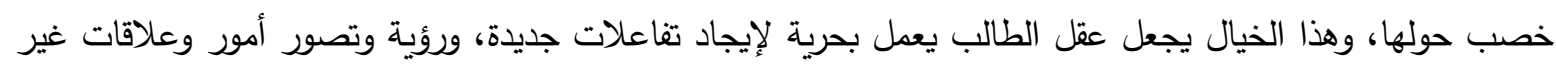
واضحة قبل ذلك، لأن الخيال هو الشريك القوي لعملية الإبداع.

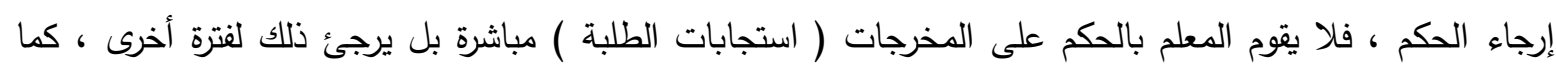
يجب ممارسة نقد واقعي وبناء للأفكار المعروضة. 
يساعد المعلم الطلبة على أن يكونوا حساسية للمشكلات ( المعرفية - الاجتماعية - الشخصية ). فأول مرتكز لعملية التفكير الإبداعي هو الحساسية للمشكلات.

على المعلم أن ينمي الفضول عند الطلبة، والفضول هنا ييعني الميل لمعرفة الأشياء كل أنواع الأشياء فقط لمعرفتها، فالمعرفة لديه ممتعة وغالبا ما تكون مفيدة، التحدي: ينبغي على المعلم أن يبني جانب التحدي عند الطلاب في مواجهة

المشكلة.

الثكوكية: على المعلم أن يعرف أن الإبداع يسير في خط لا منته فعلى الطالب أن يكون شكاكا في الحلول والمعالجات

$$
\text { التي طرحت للمشكلة حتى ينتج أشياء أخرى. }
$$

يجب عرض مشكلات واقعية من داخل المجتمع وتمس حياة الفرد على أن تكون المشكلة محددة وليست عامة.

\section{مشكلة الدراسة:}

إن اهتمام المجتمعات الإنسانية بالإبداع يعود إلى التطورات العلمية الكبيرة التي يشهدها عصرنا الحالي، والتي تقتضي

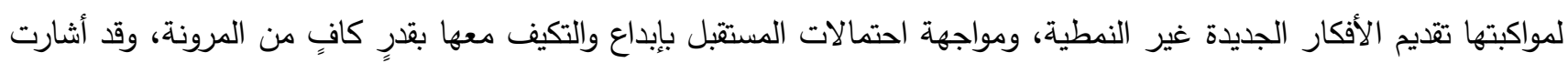
معظم البحوث إلى أن الإبداع مهم في تحسين عملية حل المشكلات بتزويد الأفراد بأدوات حل المشكلة، ويزيد من فاعلية إتخاذ

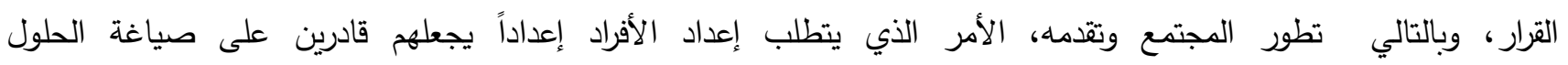
الجديدة(Mathers,2001). ونظراً لأهية الإبداع في إحداث التطور في المجالات كافة ترى جميع المؤسسات، وفي شتى المجالات التربوية والسياسية والاقتصادية ضرورة تتمية لاى أفرادها لتكون قادرة على النمو والتطور (Carling, 2015) وتؤدي المدرسة دوراً

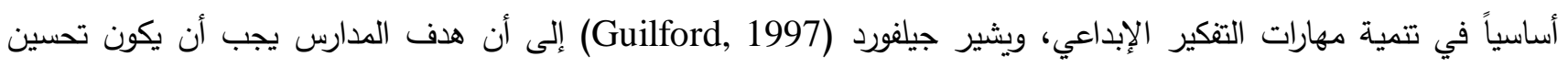
مهارات التفكير الإبداعي لدى الطلبة، بإثارة الأنشطة الصفية التي تساعد الطالب على التى أن يكون متقصياً، ومكتشفاً (Fobes,2001). ويعد المعلم في جميع المراحل الدراسية الأساس الأول في عملية التعليم، ويمثل حجر الزاوية للعملية التعليمية، ومفتاح النجاح لأي برنامج مدرسي (Higgin \& Morgan, 2014). ويلعب المعلم أيضاً دوراً أساسياً في تتمية مهارات التفكير للى الطلبة، وتعد مرحلة التعليم الأساسي الفترة التي يرسي فيها الطالب الأسس لكثير من جوانب شخصيته؛ فالمعارف والاتجاهات والمهارات التي يكتسبها الطالب في هذه المرحلة تمثل الركائز الأصيلة التي يعتمد عليها نموه في المراحل التالية، وتترك أثارها المتميزة على معالم شخصيته، ومدى توافقه الشخصي والاجتماعي؛ إذ ينمو حب الاستطلاع لديه، وتزداد قدراته اللغوية والعددية، وتزداد محصلته اللغوية، ويتحول تفكيره من تفكير حسي إلى تفكير مجرد. وغيرها من الخصائص المعرفية والعقلية التي تمكن المعلم

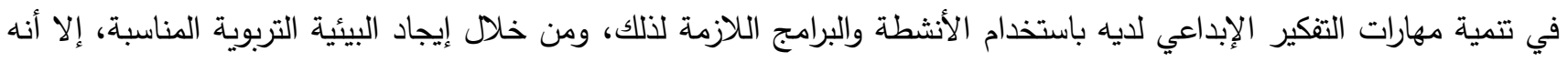
يمكن أن يكون استخدام المعلم للأساليب التقليدية في التدريس، والتي يكون التركيز فيها على الحفظ والاسترجاع دون مراعاة لقدرات الطلبة على الاكتشاف، وأساليب التقويم التي يتم التركيز فيها على الإجابة المحددة لأسئلة المدرس معيقة لنمو المهارات الإبداعية

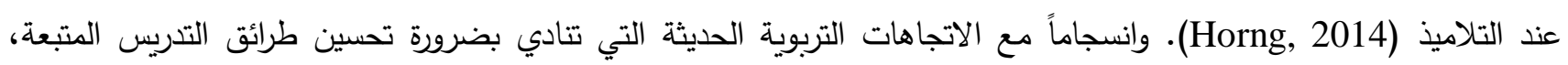
وتبني استراتيجيات وأساليب أكثر فاعلية، تساعد على تتمية وصقل المهارات الإبداعية لدى الطلبة، ومحاولة طرح أفكار إبداعية جديدة يمكن أن تثري المادة العلمية. وبذلك تكمن مشكلة الدراسة في التعرف إلى مستوى استخدام معلمي المرحلة الأساسية العليا لأساليب تتمية التفكير الإبداعي لدى طلبتهم في المدارس الحكومية في محافظة طولكرم من وجهة نظر هؤلاء الطلبة.

\section{أهمية الاراسة:}

تتبع أهمية الموضوع الدراسة الحالية من الناحيتين النظرية والتطبيقية كالآتي: 
ا. تتبع الأهمية النظرية للدراسة بما تضيفه من أدبيات نظرية ترفد المكتبة التربوية المحلية والعربية بمعارف جديدة حول مهارات التفكير الإبداعي لدى المعلمين. r. اعتبار موضوع التفكير الإبداعي من المواضيع الحديثة والمهمة التي حظيت باهتمام الفكر التربوي العربي، لحاجته الماسة

$$
\text { في مواكبة التطورات التربوية المعاصرة. }
$$

r. تكمن أهمية هذه الدراسة بأن الإنتاج الكلي للأفكار يتقدم ويتطور بتقدم العمر ويصل إلى قمته في الفترة العمرية ما بين السابعة عشر والخامسة والثثلثين، وأن الإنتاج ذات الجودة العالية يصل إلى قمته في نفس هذه الفترة العمرية، وأن هنالك علاقة بين الإبداع والذكاء ومعنى ذلك أنه يمكن تتمية الإبداع عن طريق تتمية الذكاء بالتحصيل الدراسي واستخدام المعلمين للوسائل ذات العلاقة المباشرة في تتمية الإبداع لدى الطلبة والتي تكون مقدمتها المرحلة الدراسية الأساسية، وهذه الفترة إذا ما تم الاهتمام والاعتتاء بالطلبة وتتمية قدراتهم فان التوقعات تكون عالية لمستوى أدائهم في المستقبل.

الأهمية التطبيقية:

ا. ـ توجه أنظار المؤسسات القائمة على إعداد المعلمين إلى مكامن الضعف في برامج الإعداد؛ لإعادة النظر فيها، ما يوجه

$$
\text { هذه البرامج نحو التطوير الثامل لمكونات البرنامج. }
$$

r. تسهم في تطوير الإشراف التربوي في إعداد نموذج لوسيلة تقويم أداء معلم المرحلة الأساسية في مجال تتمية التنكير الإبداعي.

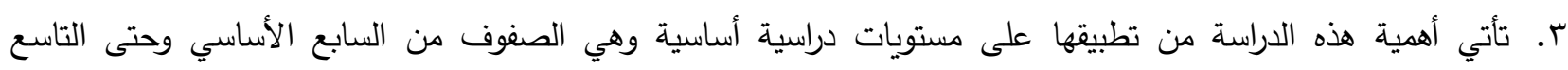
الأساسي، الأمر الذي يمنح نتائج هذه الدراسة فرصة أكبر في التطبيق على مراحل عمرية صغيرة نسبياً للتعميم، وبصورة

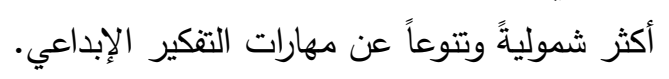

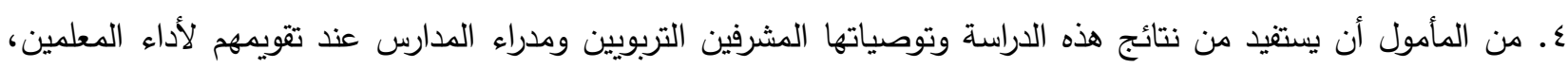
وأن يتم العمل على توظيف بعض هذه النتائج من أجل تبني استراتيجيات ومهارات التفكير الإبداعي وترسيخها في العملية

ه. كما تظهر هذه الأهمية من تأثير طرق التدريس المتبعة من قبل المعلمين على تحصيل الطلبة، وعليه فإن تبني المعلمين لطرق تدريس إبداعية يمكن أن يعزز من المستوى العلمي للطلبة ويطلق العنان لإبداعاتهم، ويؤدي إلى تطوير العملية التعليمية ككل.

7. تعزز ميدان الدراسات والبحوث المحلية والعربية بدارسة حديثة في تحديد الأساليب التي يجب أن يستخدمها المعلمون لتشجيع التفكير الإبداعي لدى طلبة المرحلة الأساسية ،خصوصا وأن هناك ندرة -وحسب علم الباحث - للدراسات التي تيتناول

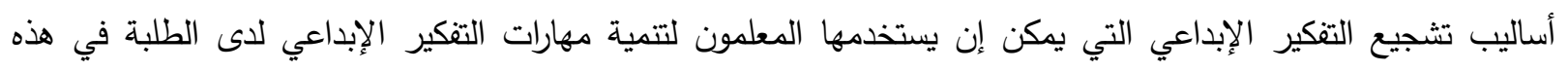
المرحلة.

أهداف الاراسة:

تهدف هذه الدراسة إلى تحقيق الأهداف الآتية: ا. التحقق من مستوى تقديرات طلبة المرحلة الأساسية العليا في المدارس الحكومية في محافظة طولكرم لمدى استخدام المعلمين لأساليب تتمية التقكير الإبداعي لديهم. 
r. التعرف إلى دلالة الفروق الإحصائية في مستوى استخدام معلمي المرحلة الأساسية العليا لأساليب تتمية التفكير الإبداعي

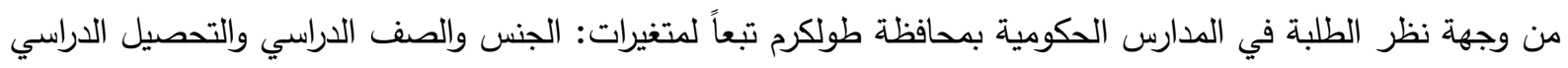

$$
\text { ومكان السكن. }
$$

أسئلة الاراسـة:

سعت هذه الدراسة للإجابة عن الأسئلة الآتية:

ا. ما درجة استخدام معلمي المرحلة الأساسية العليا لأساليب تتمية التفكير الإبداعي من وجهة نظر الطلبة في المدارس الاس

الحكومية بمحافظة طولكرج؟

ץ. هل توجد فروق دالة إحصائياً في درجة استخدام معلمي المرحلة الأساسية العليا لأساليب تتمية التفكير الإبداعي من وجهة

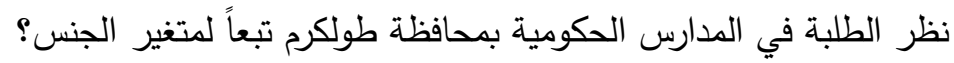
r. هل توجد فروق دالة إحصائياً في درجة استخدام معلمي المرحلة الأساسية العليا لأساليب تتمية التفكير الإبداعي من وجهة

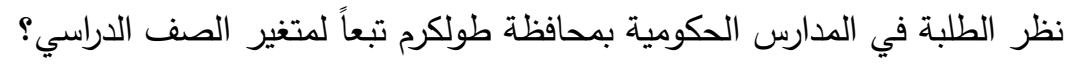
ع. هل توجد فروق دالة إحصائياً في درجة استخدام معلمي المرحلة الأساسية العليا لأساليب تتمية التفكير الإبداعي من وجهة

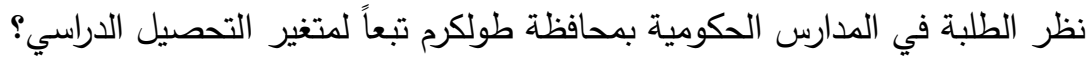
ه. هل توجد فروق دالة إحصائياً في درجة استخدام معلمي المرحلة الأساسية العليا لأساليب تتمية التفكير الإبداعي من وجهة

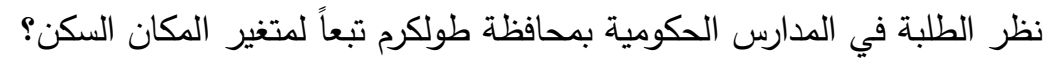

$$
\text { يمكن تعميم نتائج هذه الدراسة في حدود الجوانب الآتية: }
$$

ا. الحدود البشرية: تمت إجراءات الدراسة على عينة من طلبة المرحلة الأساسية العليا: السابع والثامن والتاسع.

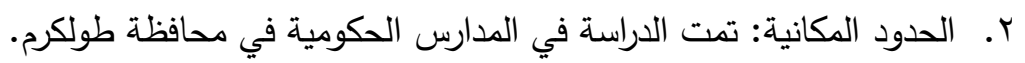

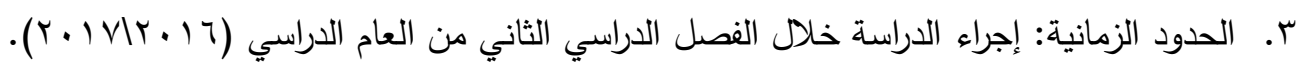
ع. الحدود الموضوعية: تعمم نتائج هذه الدراسة في حدود عينتها ومتغيراتها وأداتها المستخدمة. مصطلحات الدراسة:

• التفكير الإبداعي: هو مزيج من القدرات والاستعدادات والخصائص الثخصية التي إذا ما وجدت بيئة مناسبة يمكن أن ترقى بالعمليات العقلية لتؤدي إلى نتاجات أصيلة وهذه سواء بالنسبة لخبرات الفرد السابقة أو خبرات المؤسسة آو المجتمع أو العالم

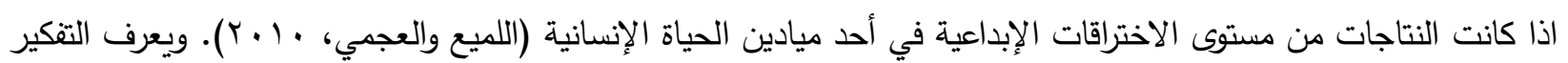
الإبداعي إجرائياً في هذه الدراسة بالدرجة الكلية ولدرجات الفرعية التي يحصل عليها الطالب على الاستبانة المعدة لهذا الغرض. مرحلة التعليم الأساسية العليا: هي مرحلة متوسطة ما بين مرحلة الأساسية الدنيا (من الصف الأول وحتى الثالث) والمرحلة

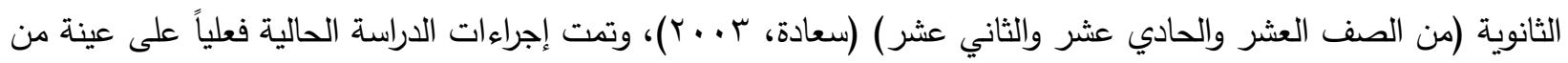
طلبة الصفوف السابع والثامن والتاسع لضمان قدرتهم للتعامل مع أداة الدراسة. 
أجرى الباحثون في التربية وعلم النفس دراسات عديدة ومتتوعة بحثت في استخدام التفكير الإبداعي في التدريس، فقد قام ستروم وستروم (Strom \& Strom, 2016) التعرف إلى اتجاهات المعلمين في تحديد التنكير الإبداعي المتوقع من الطلبة، تم

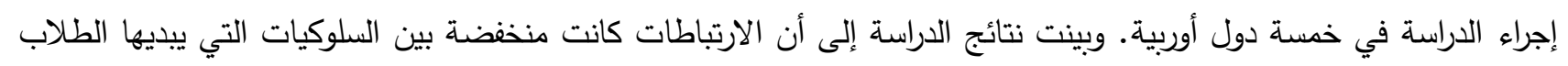
المبدعون، فالمعلمون من الدول الخمس لم يعطوا أهمية للسلوك الإبداعي للطلبة الذي تمثل في طرحهم أسئلة كثيرة، وقدرتهم على الإتى

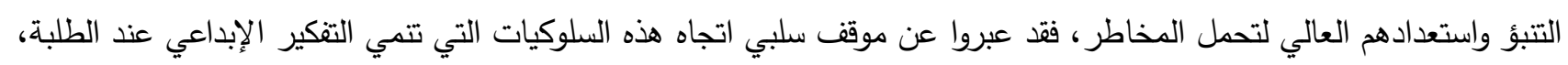

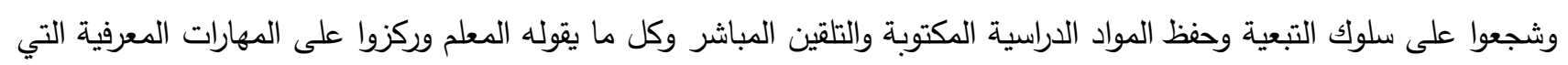
تعكس كفاءتهم الذاتية

وهدفت دراسة دانيل (2014, Daniel) إلى المقارنة بين اتجاهات المعلمين نحو تتمية مهارات التفكير لطلبتهم كهدف من

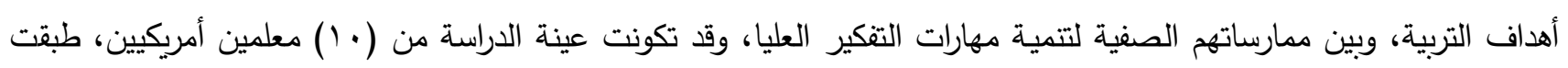

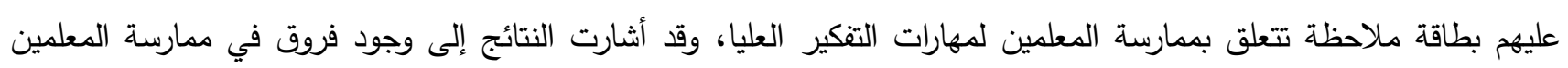
لتتمية مهارات التفكير العليا لصالح المعلمين الذين اظهروا اتجاهات ايجابية نحو إدراكهم لمفهوم التتكير كهدف من أهداف التعليم. وقام هورنق ومورجان (Higgins \& Morgan, 2014) دراسة بعنوان المعلمين المبدعين واستراتيجيات التدريس

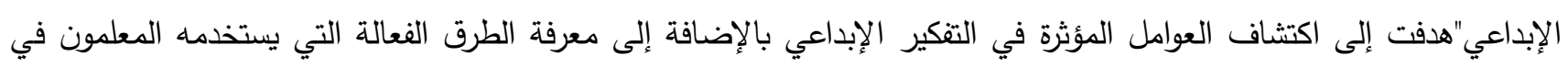
مجال التعليم المتعلق بالأنشطة المتكاملة، استخدم الباحث أدوات تمثلت في المقابلة الجماعية، والملاحظة الصفية، تحليل المحتوى.

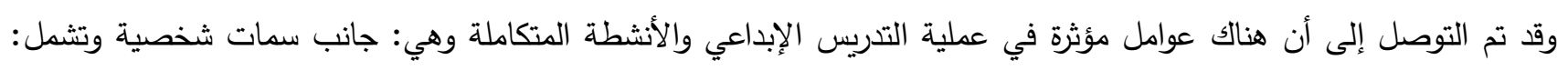

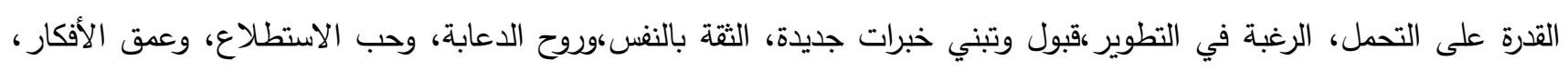

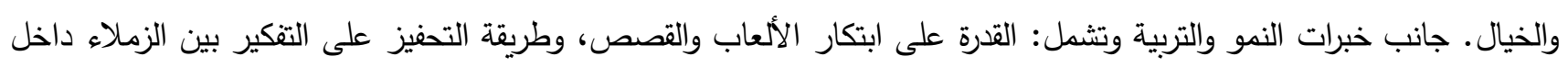

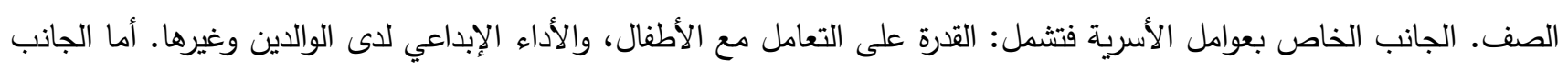
الإداري والتوجيهي الذي تقوم به الهيئة التدريسية فيشمل على: الإيمان بمهنة التعليم والعمل الجاد.

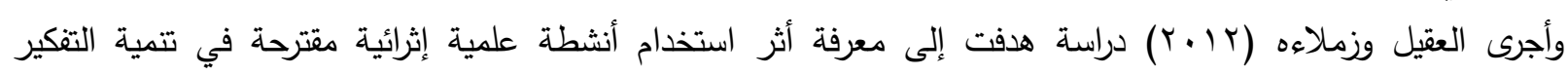
الإبداعي لدى التلاميذ الموهوبين في الصف السادس الابتدائي. تم استخدام المنهج شبه التجريبي في الدراسة. تكونت عينة الدراسة

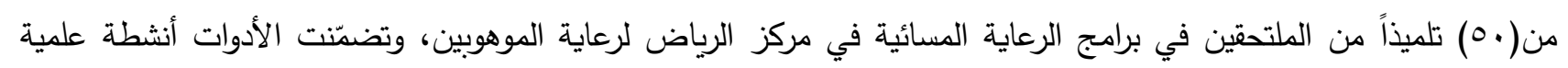

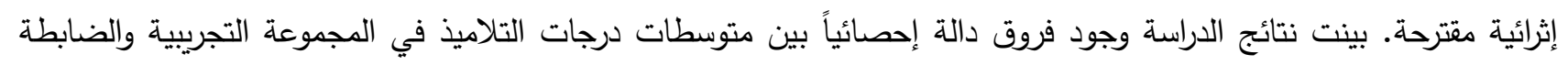

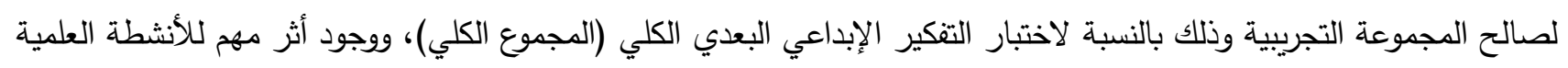
الإثرائية المقترحة على مهارات التنكير الإبداعي.

وقام اللميع والعجمي (• ( ب) بدراسة بهدف التعرف إلى مدى تأثر التعلم التعاوني في تتمية القدرة على التفكير الإبداعي عند طلبة المستوى الثالث في ثانوية المقررات في دولة الكويت، فقام الباحثان باختبار صحة فرضية الدراسة والذي مؤداه: أنه توجد فروق دالة إحصائياً بين المجموعتين التجريبيتين (التي درست بطريقة التعليم التعاوني) والضابطة (التي درست بطريقة تقليدية) في درجة نمو القدرة على التفكير الإبداعي لصالح المجموعة التجريبية، ثم استخدام اختبار للكثف عن الفروق بين المجموعتين التي تم تدريسها بطريقة التعلم التعاوني حيث كان أدوأها على مقياس القدرة على التفكير الإبداعي أفضل من أداء المجموعة الضابطة التي درست بطريقة تقليدية. 
وهدفت دراسة العبويني (^ . . ب) الكثف عن أساليب التعليم والسلوك القيادي والتكيف الاجتماعي لاى الطلبة الموهوبين في الأردن، واستخدمت الدراسة المنهج الوصفي المسحي، وتكونت عينة الدراسة من جميع الطلبة الموهوبين في مدرسة اليوبيل، والبالغ

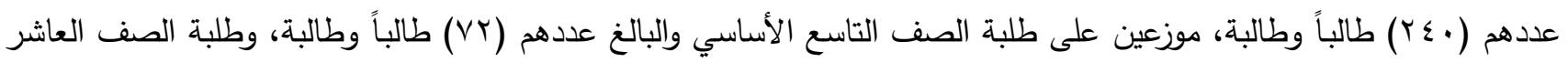
والبالغ عددهم (•9) طالباً وطالبة، وطلبة الصف الحادي عشر والبالغ عددهم (V^) طالباً وطالبة، وتوصلت الدراسة إلى نتائج أهمها: أن الطلبة الموهوبين يستخدمون الأسلوب البصري في التعلم بشكل مرتفع حيث جاء هذا الأسلوب في المرتبة الأولى، والأسلوب الحركي بشكل مرتفع أيضًا وجاء بالمرتبة الثانية، وفي المرتبة الأخيرة وبدرجة متوسطة الأسلوب السمعي.

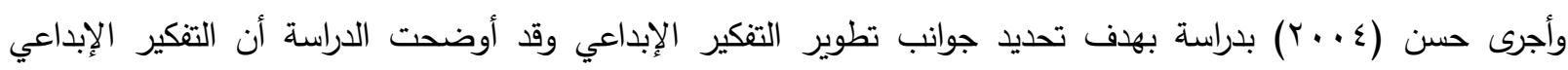
يتضمن الطلاقة والمرونة حيث إن طلاقة الطالب تتطلب قدراً قليلاً من المعلومات أما المرونة في التفكير فإنها تتطلب كما كبيراً من المعلومات بهدف تتمية التقكير الإبداعي وحل مشكلاته ومعوقاته أما علاقة التفكير الإبداعي بالتحصيل الدراسي فانه يرتبط بالجها الذهني الذي يبذله المتعلم في المواقف التعليمية كذلك فان نتاجات التحصيل ترتبط بالجهود الذهنية التي يبذلها المتعلم وعوامل الاستعداد لديه.

أما العتوم (ع ـ ـ ץ) فقد قام بدراسة هدفت إلى معرفة مدى تركيز كتب اللغة العربية ومعلميها للمرحلة الثانوية في الأردن على مهارات التفكير الناقد والإبداعي وقد تكونت عينة الدراسة من خمسة معلمين وخمس معلمات يدرسون اللغة العربية للمرحلة الثانوية للعام الدراسي(ع ـ ـ ب) وتم اختيار العينة بالطريقة العشوائية البسيطة، وقد أستخدمت فيها قائمتا تقدير : الأولى( لمهارات التفكير الناقد والثانية لمهارات التفكير الإبداعي، وقد أوضحت النتائج أن نسبة التركيز على صعيد التنكير الإبداعي قد بلغت في المنهاج المكتوب(؟ •r\%) وفي المنفذ(0, §\%)؛ مما يدل على تدنٍ ملحوظ في مدى تركيز معلمي اللغة العربية على أسلوب التفكير الإبداعي. وهدفت دراسة أبو عجمية (ع . . ب) معرفة دور منهاج اللغة العربية للصف الثامن الأساسي في تتمية التفكير الإبتكاري للى طلبة منطقة بيت لحم والخليل، وقد تكونت عينة الدراسة من (•^) معلماً ومعلمة، طور الباحث استبانة تصف منهاج اللغة العربية بمعناه الثامل والمتكامل، واستبانة أخرى لتحديد ميسرات ومعيقات التفكير الإبتكاري، ثم قام أيضاً بتحليل المحتوى لبعض دروس منهاج اللغة العربية للصف الثالث الأساسي كما قام بإجراء مقابلة مع مجموعة من المعلين على شكل مجموعة بؤرية كأداة إضافية لجمع البيانات، وكان من النتائج التي توصل إليها الباحث أن منهاج اللغة العربية يوفر فرصاً للتنكير الإبداعي بدرجة متوسطة، وكان من أبرز ميسرات التفكير الإبتكاري في المنهاج تتمية الثعور بالثقة لاى الطلبة، وأبرز معيقاته عدم كفاية الوقت المحدد للنشاط المدرسي، وطول المنهاج. كما أجرت قشوع ( ( . ب) دراسة هدفت إلى معرفة وجهة نظر طلبة الصف الثامن الأساسي في الدور الذي يقوم به معلم

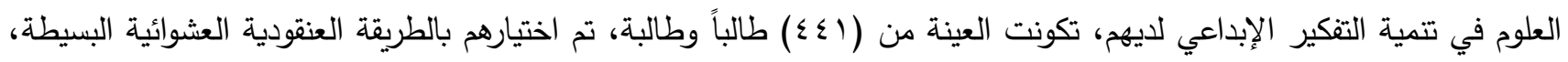

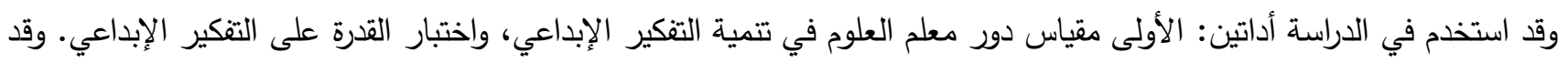

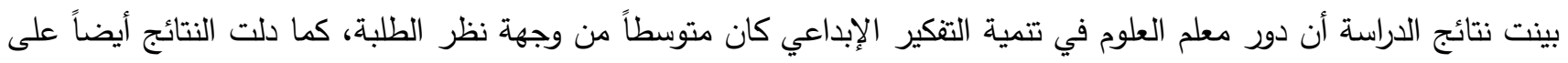

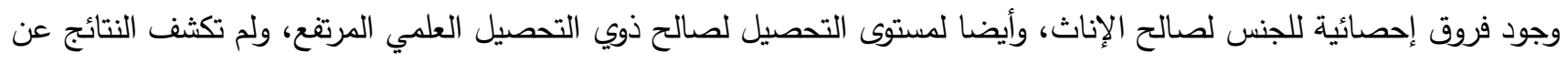
وجود فروق في التفاعل المشترك بين الجنس ومستوى التحصيل العلمي. 
وهدفت دراسة أونيسكو (Onosko, 1990) معرفة اتجاهات المعلمين نحو تتمية مهارات التفكير لطلبته كهدف من أهداف التربية، وبين ممارساتهم الصفية لتتمية مهارات التفكير العليا، وقد تكونت عينة الدراسة من (• ( ) معلمين أمريكيين، طبقت عليهح بطاقة ملاحظة تتعلق بممارسة المعلمين لمهارات التفكير العليا، وقد أشارت النتائج إلى وجود فروق في ممارسة المعلمين لتتمية مهارات التفكير العليا لصالح المعلمين الذين اظهروا اتجاهات ايجابية نحو إدراكهم لمفهوم التنكير كهدف من أهداف التعليم. أما دراسة جيرجوفك ورايف (Gerjovch \& Wrigh, 1988) فقد هدفت إلى الوقوف على العلاقة بين مستوى التعليم لاى منى الدئ

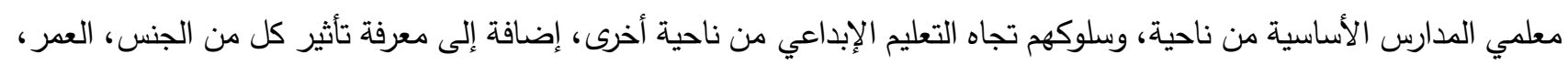

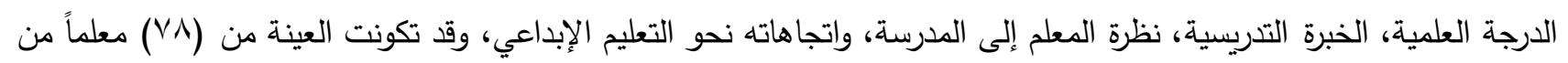

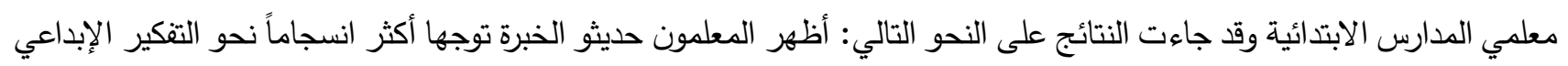
مقارنة بالمعلمين ذوي الخبرة الطويلة. كما دلت النتائج على عدم وجود علاقة ذات دلالة بين فلسفة المعلم واتجاهاته نحو التعليم الإبداعي باختلاف الجنس، العمر ، والدرجة العمية. وهدفت دراسة نشواني (910) معرفة علاقة الابتكار بالذكاء والتحصيل الدراسي، حيث بينت نتائجها أن التقوق التحصيلي يتزود بدرجة في الاستعداد الذهني للتعلم والتقوق التحصيلي يرتبط بنسبة الذكاء بدرجة عالية تصل الى معامل ارتباط مقداره (•V, • • ) لذلك فان المتفوق تحصيلياً يمكن أن يكون مبدعا ولكن المبدع قد لا يكون متفوقا تحصيلياً.

من خلال استعراض الدراسات السابقة يلاحظ: أن هناك تبايناً في مستوى ممارسة المعلمين الذين شملتهم الدراسات لأساليب تتمية التثكير الإبداعي، إذ أثارت دراسة (Gerjovch \& Wrigh, 1988 ؛Strom \& Strom, 2016)

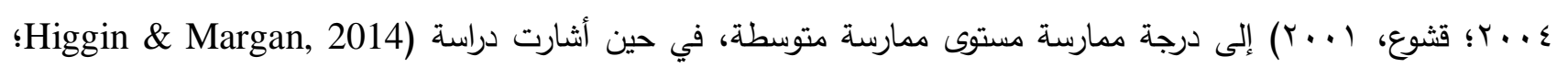

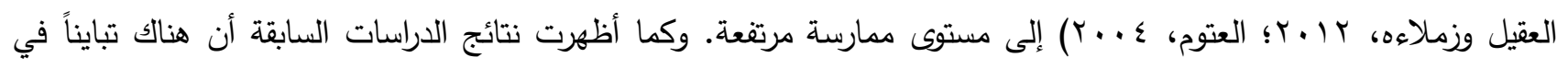

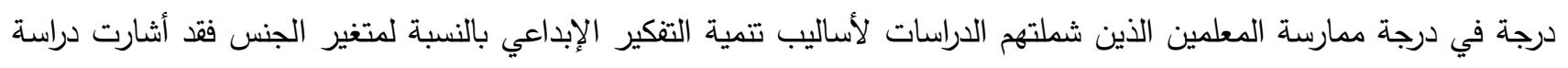
(Gerjovch \& Wrigh, 1988)

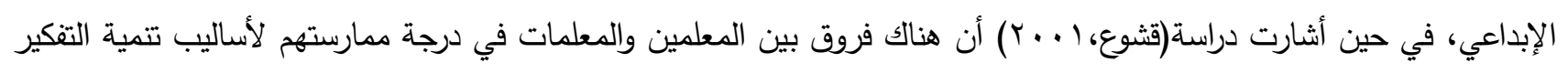

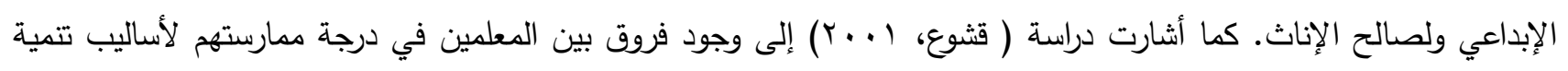

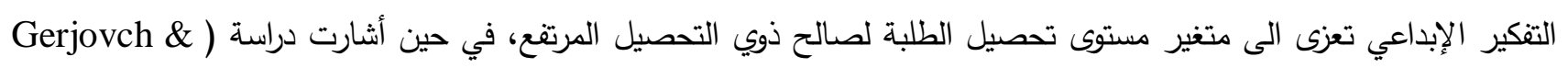
(Wrigh, 1988 إلى عدم فروق بين المعمين في درجة ممارستهم لأساليب تشجيع التفكير الإبداعي تعزى الى متغير التحصيل.

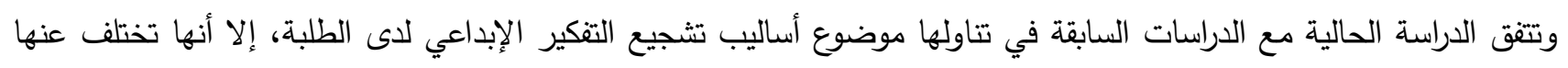

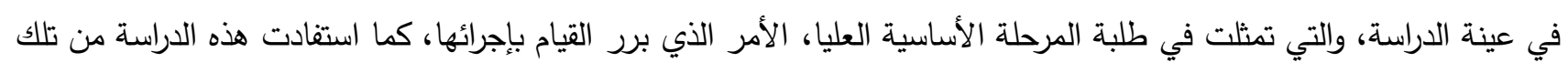
الدراسات في تطوير أداتها، والإجراءات المتبعة.

الطريقة والإجراءات:

أولاً: منهج الاراسة:

استخدم المنهج الوصفي التحليلي لمناسبته طبيعة هذه الدراسة وأهدافها.

ثانياً: مجتمع الدراسة:

تكون مجتمع الدراسة من جميع طلبة المرحلة الأساسية العليا في محافظة طولكرم من الصفوف السابع والثامن والتاسع، والبالغ

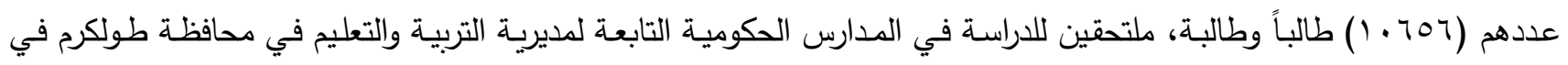
¿े 


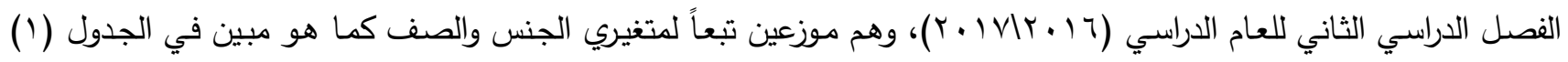
الجدول (1) إ: توزع مجتمع الدراسة تبعاً لمتغيري الجنس والصف

\begin{tabular}{|c|c|c|c|}
\hline المجموع & الإناث & الذكور & \\
\hline$r \leqslant r_{0}$ & 1711 & INIV & السابع \\
\hline rovq & $I V \leqslant V$ & IATr & الثامن \\
\hline TT\&Y & $1 V \cdot T$ & 1947 & التاسع \\
\hline 1.707 & 0.81 & 0010 & المجموع \\
\hline
\end{tabular}

عينة الاراسة:

تكونت عينة الدراسة (r£乏) طالباً وطالبة من الصفوف العليا لمرحلة التعليم الأساسي، تم اختيارهم بطريقة عشوائية طبقية

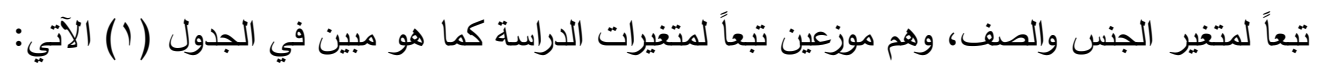
الجدول (ץ): توزع عينة الاراسة تبعاً لمتغيراتها المستقلة فئس الجدول

\begin{tabular}{|c|c|c|c|}
\hline النسبة المئوية & العدد & المستوى & المتغير \\
\hline \%०r & rr. & الذكور & \multirow[t]{2}{*}{ الجنس } \\
\hline$\% 乞 \wedge$ & YIT & الإناث & \\
\hline$\%$ \%r & $1 \leqslant 1$ & السابع & \multirow[t]{3}{*}{ الصف } \\
\hline \%rr & $1 \leq 7$ & الثامن & \\
\hline \%ro & 100 & التاسع & \\
\hline$\%$ \% & $1 . r$ & مرتفع & \multirow{3}{*}{ التحصيل الاراسي } \\
\hline$\% \leqslant 0$ & 199 & متوسط & \\
\hline$\%$ \%r & $1 \leqslant 1$ & منخفض & \\
\hline$\% \longleftarrow \varepsilon$ & 10. & مدينة & \multirow{3}{*}{ مكان السكن } \\
\hline \%or & rT. & قرية & \\
\hline$\%$ १ & Tr & مخيم & \\
\hline
\end{tabular}

رابعاً: أداة الدراسة:

تكونت أداة الدراسة من استبانة أعدها الباحث وتحتوي على (§؟) فقرة، تشير كل منها إلى أسلوب معين من أساليب تتمية التفكير الإبداعي قد يستخدمها المعلم في غرفة الصف، موزعة إلى مجالين هما: مجال التشجيع والتحفيز ويشتمل على (؟ ب) فقرة

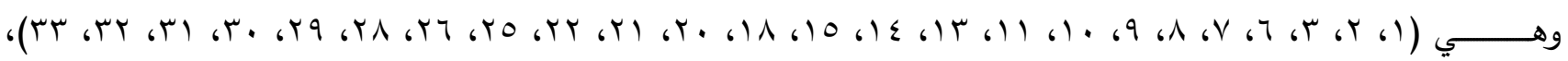

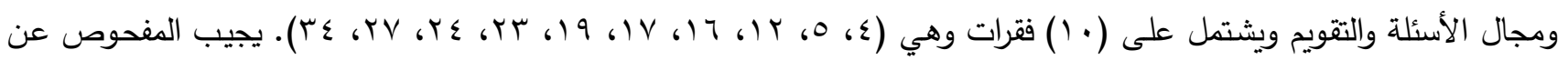

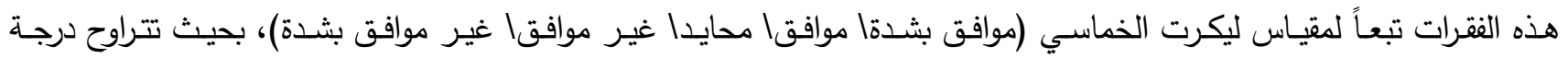

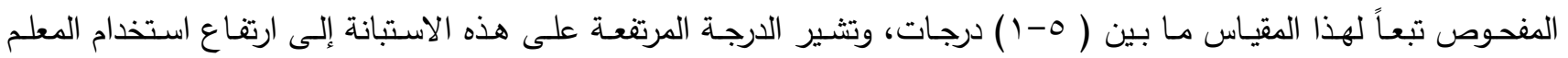
للأسلوب بينما تشير الدرجة المنخفضة عليها إلى انخفاض مستوى استخدام المعلم لهذا الأسلوب لتتمية التفكير الإبداعي لدى الطلبة. ولتفسير استجابات الطلبة وتقديراتهم لمدى استخدام المعلمين لأساليب التفكير الإبداعي اعتمد المعيار النسبي الآتي: 
الحد الأعلى للإجابة - الحد الأدنا للإجابة \ب + انحراف معياري واحد

$$
\text { 1. } r=r|\varepsilon=1+r| 1-0=
$$

مستوى قليل لاستخدام أساليب تتمية التفكير الإبداعي

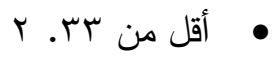

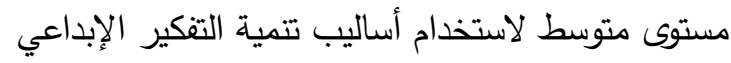

• • بين (Tr.

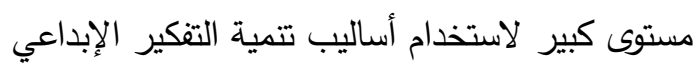

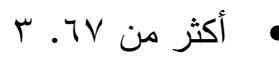

صدق أداة الدراسة وثباتها:

تم التحقق من صدق الاستبانة بطريقة صدق المحكمين بعرضها على مجموعة من أساتذة الجامعة وعددهم (9) طلب

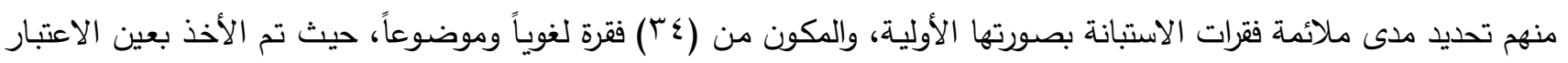

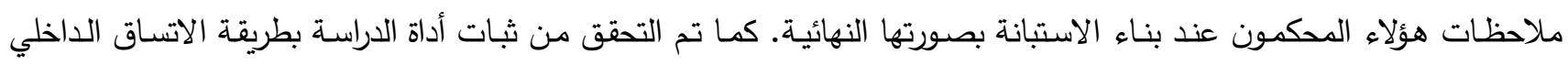

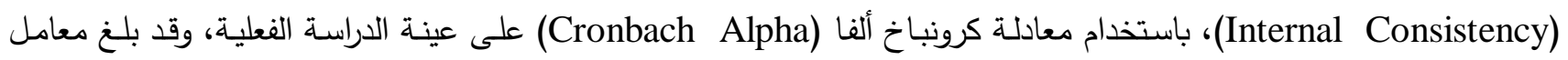

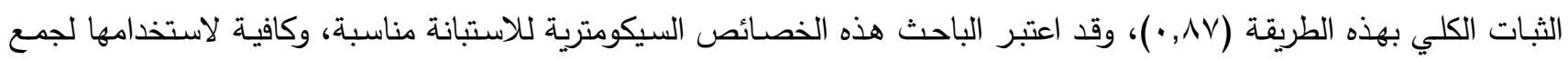

البيانات لتحقيق أهداف هذه الدراسة

خامساً: المعالجات الإحصائية:

من اجل معالجـة البيانـات تم استخدام حزمـة البرامج الإحصـائية للعلوم الاجتماعيـة (spss) وذلك باستخدام المعالجـات الإحصائية الوصفية والتحليلية اللآتية:

ا ـ المتوسطات الحسابية والانحراف المعياري والنسب المئوية.

r. اختبار ( ت) لمجموعتين مستقلتين (Independent-Samples T-test ).

r. تحليل التباين الأحادي( (One Way ANOVA).

نتائج الاراسة ومناقثتهها:

أولا: النتائج المتعلقة بالسؤال الأول وهو: ما مستوى استخدام معلمي المرحلة الأساسية العليا لأساليب تنمية التفكير الإبداعي

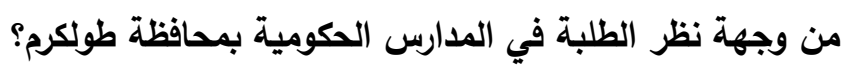
للإجابة عن هذا السؤال حسبت المتوسطات الحسابية والانحرافات المعيارية والنسب المئوية لكل فقرة من فقرات الإستبانة، كما اعتمد معياراً محدداً لتفسير هذه المتوسطات كما هو مبين في الجدول (ب) الآتي:

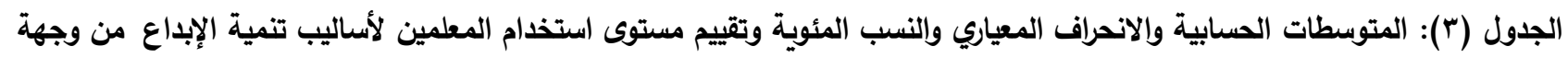
نظر الطلبة

\begin{tabular}{|c|c|c|c|c|c|c|}
\hline التقييم & المئوية & المعياري & الحسابي & 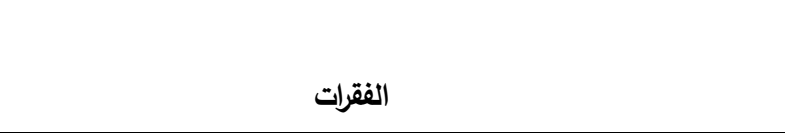 & التسلسلي & الترتيبي \\
\hline كبير & 87.83 & 0.53 & 4.39 & يرحب المعلم بأسئلة الطلبة الخارجية في مجال الموقف التعليمي الصفي & $r$ & 1 \\
\hline كبير & 87.61 & 0.66 & 4.38 & يكلف المعلم الطلبة نشاطات إثرائية تبرز التنكير الإبداعي لليهخ & $\varepsilon$ & 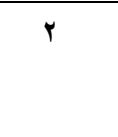 \\
\hline كبير & 86.60 & 0.70 & 4.33 & يشجع المعلم الأفكار الجديدة التي تطرح في الموقف التعليمي & r & $r$ \\
\hline كبير & 86.40 & 0.78 & 4.32 & يعزز المعلم روح المثابرة والتنافس الإيجابي بين الطلبة & $r$. & $\varepsilon$ \\
\hline
\end{tabular}




\begin{tabular}{|c|c|c|c|c|c|c|}
\hline 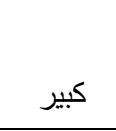 & 86.00 & 0.71 & 4.30 & يمهذ المعلم للموقف التعليمي الصفي بإثارة أسئلة تفكيرية عليا & 1. & 0 \\
\hline كبير & 85.80 & 0.58 & 4.29 & | يبتكر أساليب جديدة لمعالجة المشكلات المطروحة & 1 & 9 \\
\hline كبير & 85.43 & 0.68 & 4.27 & | يستخدم أسلوب مجموعات النقاش & iv & V \\
\hline كبير & 85.00 & 0.61 & 4.25 & | يطرح أفكار غريبة للنقاش & 0 & $\wedge$ \\
\hline كبير & 85.00 & 0.64 & 4.25 & يشجع الطلبة على قبول ما هو غير مألوف من الأفكار & 9 & 9 \\
\hline كبير & 84.57 & 0.59 & 4.23 & | يميل الى إعطاء معلومات بطريقة مثيرة للشك & $1 \leq$ & 1. \\
\hline كبير & 84.20 & 0.78 & 4.21 & | يطرح اسئلة تكون مقدمة لأسئلة اخرى & 19 & 11 \\
\hline كبير & 84.00 & 0.71 & 4.20 & | يطرح اسئلة عن العلاقات بين الأشياء & ir & ir \\
\hline كبير & 82.17 & 0.69 & 4.11 & | يحاور الطلبة لحل مشكلة ما & r & ir \\
\hline كبير & 82.00 & 0.73 & 4.10 & يوظف أسئلة في مستوى التركيب & 17 & $1 \leq$ \\
\hline 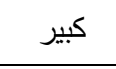 & 81.80 & 0.75 & 4.09 & | يطلب من طلبته أكثر من طريقة للحل & 11 & 10 \\
\hline 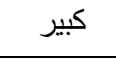 & 81.60 & 0.73 & 4.08 & | يستخلص الإجابة من بين إجابات الطلبة & 7 & 17 \\
\hline كبير & 81.52 & 0.60 & 4.08 & |يوظف اسئلة تفريقية & ir & iv \\
\hline كبير & 80.82 & 0.85 & 4.04 & 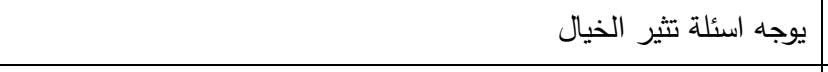 & $\wedge$ & 11 \\
\hline كبير & 79.78 & 0.83 & 3.99 & | يعطي اسئلة مفتوحة النهاية & rr & 19 \\
\hline كبير & 79.40 & 0.87 & 3.97 & | يقدم حلولا غير مكتملة للطلبة & $r \leq$ & $r$. \\
\hline 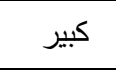 & 77.17 & 0.87 & 3.86 & | يفسر للطلبة معاني الأشياء & 10 & $r_{1}$ \\
\hline متوسطة & 72.40 & 0.97 & 3.62 & | يشجع الطلبة للتعبير عن أفكارهم & $r r$ & $r r$ \\
\hline متوسطة & 69.00 & 1.02 & 3.45 & | يصغي الى أفكار الطلبة باهتمام & ro & $r r$ \\
\hline متوسطة & 67.42 & 1.18 & 3.37 & | يساعد الطلبة على تعزيز أنفهم عند تحقيق هدف جديد & rr & $r \leq$ \\
\hline متوسطة & 63.40 & 0.70 & 3.17 & | يمهد للدرس بأسئلة منشطة & $r \varepsilon$ & ro \\
\hline متوسطة & 62.40 & 1.00 & 3.12 & |دوره محفز للتقكير أكثر من كونه تلقينيا & $r \wedge$ & r \\
\hline متوسطة & 61.20 & 0.92 & 3.06 & | يحفز الطلبة على إكمال الأفكار الناقصة & $v$ & $r v$ \\
\hline 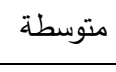 & 60.61 & 0.77 & 3.03 & | يشجع الطلبة على البحث المستمر & 11 & $r \wedge$ \\
\hline متوسطة & 60.60 & 1.10 & 3.03 & | يعدل خطته تبعا للموقف التعليمي & Yr & rq \\
\hline متوسطة & 60.39 & 1.16 & 3.02 & | يعرض المحتوى التعليمي بطريقة غير تقليدية & rq & $r$. \\
\hline متوسطة & 60.20 & 1.10 & 3.01 & يطرح على الطلبة بعض الأسئلة السابرة العميقة & rv & r \\
\hline 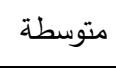 & 57.78 & 1.10 & 2.89 & | يستخدم أسلوب التعليم الجمعي & 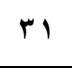 & rr \\
\hline متوسطة & 52.39 & 1.16 & 2.62 & | يدير حلقة النقاش في غرفة الصف بشكل فعال & $r$. & $r r$ \\
\hline متوسطة & 52.00 & 1.10 & 2.60 & | يتيح فرص متكافئة بين الطلبة للتوصل إلى نتائج الموقف التعليمي الصفي & rq & $r \varepsilon$ \\
\hline كبيز & & & & المتوسط الكلي & & \\
\hline
\end{tabular}


يتضح من الجدول (r) السابق أن تقديرات عينة الدراسة لمدى استخدام المعلمين في المرحلة الأساسية العليا لأساليب تتمية

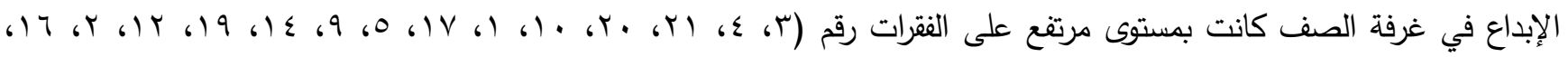

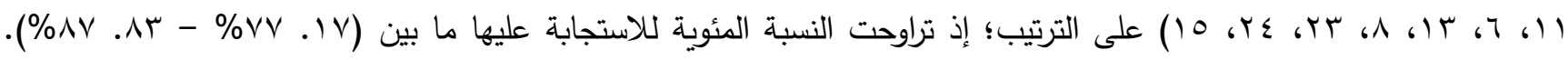

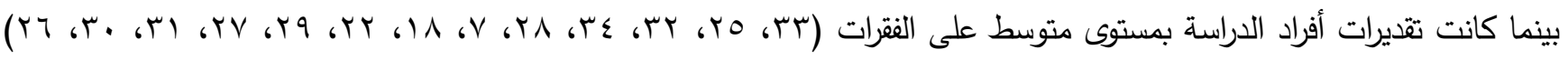

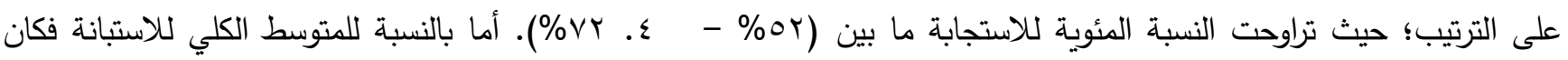

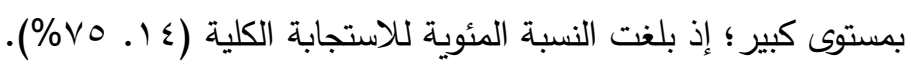

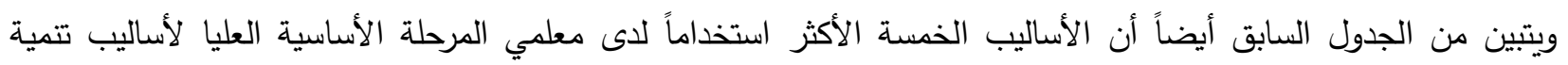
التفكير الإبداعي تبعاً لتقديرات الطلبة في الددارس الحكومية بمحافظة طولكرم وفق الترتيب التتازلي الآتي:

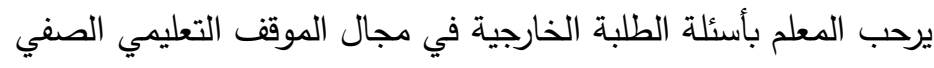

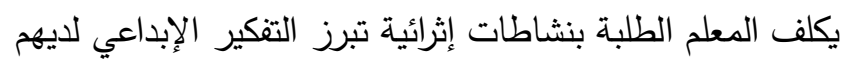

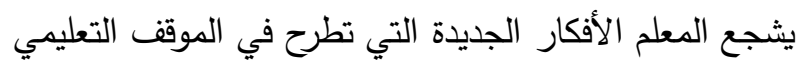

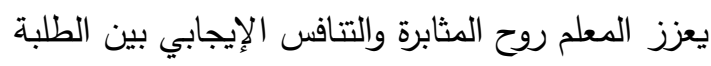

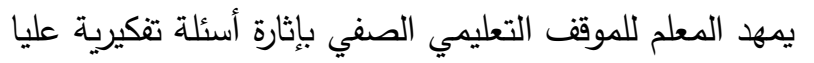
بينما كانت الأساليب الخمسة الأقل استخداماً لاى معلمي المرحلة الأساسية العليا لأساليب تتمية التنكير الإبداعي تبعاً لتقديرات الطلبة في المدارس الحكومية بمحافظة طولكرم وفق الترتيب التصاعدي الآتي: يتيح فرص متكافئة بين الطلبة للتوصل إلى نتائج الموقف التعليمي الصفي لئي يدير حلقة النقاش في غرفة الصف بشكل فعال

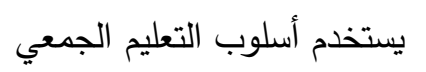

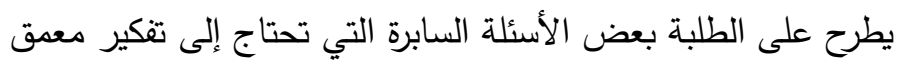

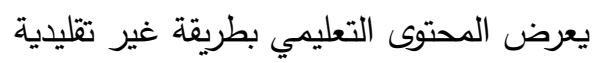
وقد عزا الباحث هذه نتائج المتمثلة بارتفاع مستوى استخدام المعلمين في المرحلة الأساسية العليا لأساليب تتمية الإبداع للأسباب

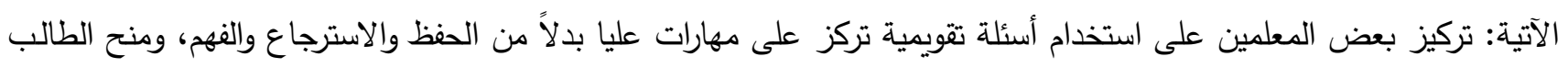
الوقت الكافي للإجابة عنها حيث إنها تحتاج إلى وقت أطول مما تحتاجه أسئلة الحفظ والاسترجاع، بالإضافة إلى عدم اهتمام

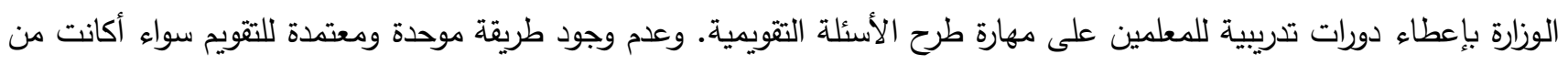
قبل كل من: وزارة التربية والتعليم، أم داخل المديرية الواحدة للمرحلة الأساسية الدنيا.

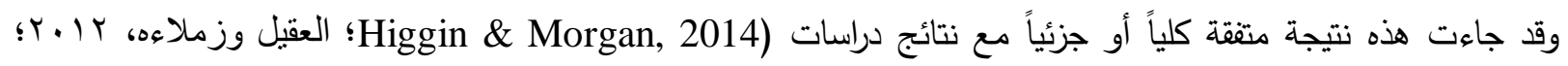

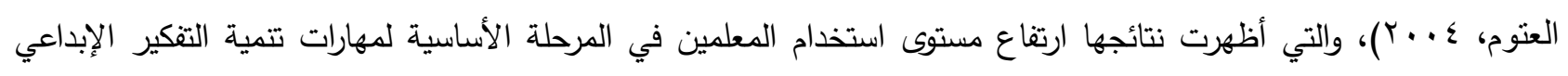

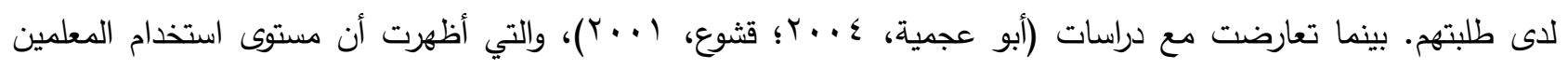
لأساليب تتمية التفكير الإبداعي للطلبة كان متوسطاً، كما تعارضت مع نتائج دراسات (Strom \& Strom, 2016؛ (4 Wrigh, 1988 \&)، والتي أظهرت انخفاض مستوى استخدام المعلمين لأساليب تتمية التفكير الإبداعي للطلبة. ثانياً:

النتائج المتعلقة بالسؤال الثاني وهو: هل توجد فروق دالة إحصائياً في مستوى استخدام معلمي المرحلة الأساسية العليا لأساليب تنمية التفكير الإبداعي من وجهة نظر الطلبة في المدارس الحكومية بمحافظة طولكرم تبعاً لمتغير الجنس؟ 
للإجابة عن هذا السؤال حسبت المتوسطات الحسابية والانحرافات المعيارية لمستوى تقديرات أفراد الدراسة لاستخدام

المعلمين لأساليب تتمية التفكير الإبداعي لطلبتهم في المرحلة الأساسية العليا تبعاً لمتغير الجنس، كما تم استخدام اختبار (ت) لمجموعتين مستقلتين ( Independent T-test ) لفحص دلالة الفروق الإحصائية بين هذه المتوسطات والمبينة نتائجه في الجدول

الجدول (ء): نتائج اختبار (ت) لالالة الفروق الإحصائية بين المتوسطات الحسابية لتقديرات أفراد الدراسة لاستخدام المعلمين لأساليب

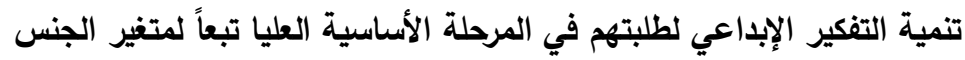

\begin{tabular}{|c|c|c|c|c|c|}
\hline مستوى الدلالة & قيمة (ت) المحسوبة & الانحراف المعياري & المتوسط الحسابي & العدد & الجنس \\
\hline \multirow[t]{2}{*}{$\cdot, \varepsilon r$} & \multirow[t]{2}{*}{ • } & • & $r, q r$ & $r r$. & الأكور \\
\hline & & & $r, 9 q$ & $r M r$ & الإناث \\
\hline
\end{tabular}

يتضح من الجدول (§) السابق عدم وجود فروق دالة إحصائياً في مستوى تقديرات أفراد الدراسة لاستخدام المعلمين لأساليب تتمية التفكير الإبداعي لطلبتهم في المرحلة الأساسية العليا تبعاً لمتغير الجنس؛ بمعنى أن تقديرات الطلبة لمستوى استخدام المعلمين

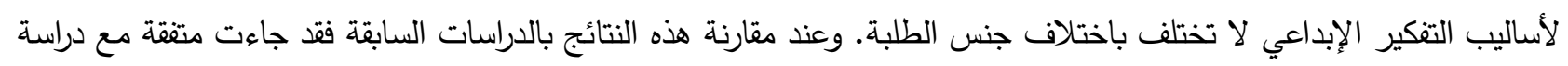

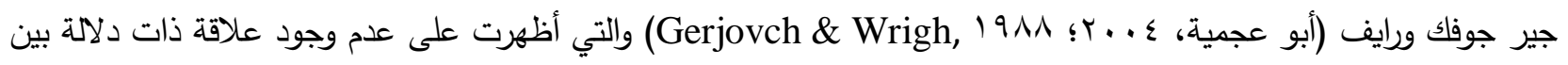

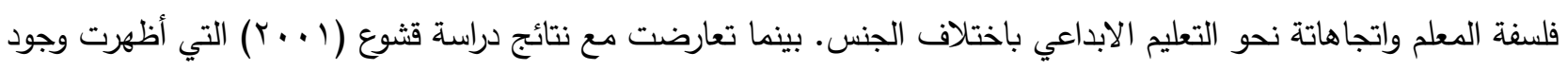

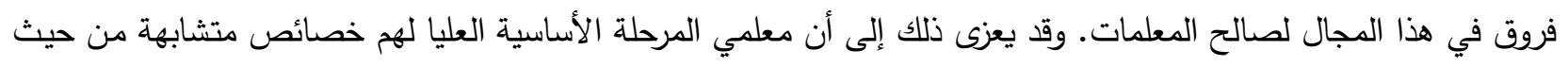
المؤهلات العلمية، والدورات التي تدربوا فيها والصفوف التي يدرسونها، ومستويات الطلبة المتشابهة، بالإضافة إلى أنهم جميعاً يستخدمون الكتب المدرسية المقررة نفسها.

ثالثاً: النتائج المتعلقة بالسؤال الثالث وهو: هل توجد فروق دالة إحصائياً في مستوى استخدام معلمي المرحلة الأساسية العليا

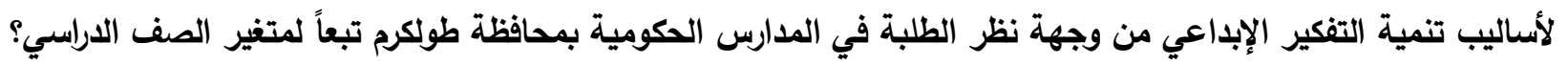

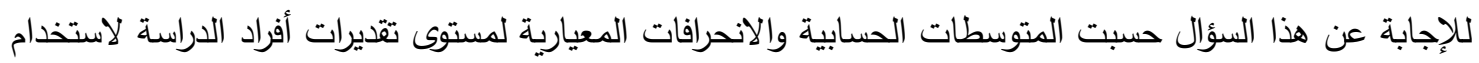
المعلمين لأساليب تتمية التفكير الإبداعي لطلبتهم في المرحلة الأساسية العليا تبعاً لمتغير الصف فكانت فئت كما هو مبين في الجدول

الجدول (ه): المتوسطات الحسابية والانحرافات المعيارية لتقديرات الطلبة لمستوى استخدام المعلمين لأساليب تنمية التفكير الإبداعي لطلبتهم تبعاً لمتغير الصف لطفي لطفيات

\begin{tabular}{|c|c|c|}
\hline الانحراف المعياري & المتوسط الحسابي & الصف \\
\hline . .0r & $r .07$ & السابع \\
\hline . & r & الثامن \\
\hline$\cdot .09$ & .9 .5 & التاسع \\
\hline •. & r.v & الكلي \\
\hline
\end{tabular}

يظهر الجدول (0) السابق وجود فروق ظاهرة في المتوسطات الحسابية لتقديرات تقديرات أفراد الدراسة لاستخدام المعلمين

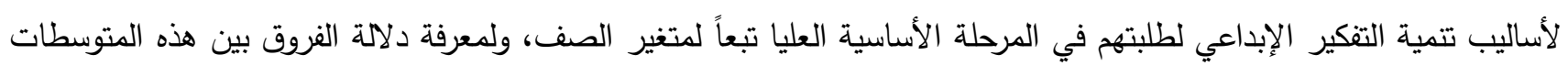

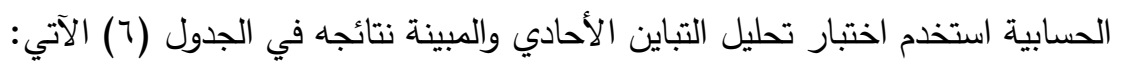


جدول (†): نتائج تحليل التباين الأحادي لتقديرات الطلبة لاستخدام المعلمين لأساليب تنمية التفكير الإبداعي لطلبتهم تبعاً لمتغير الصف

\begin{tabular}{|c|c|c|c|c|c|}
\hline مستوى الدلالة & فـ المحسوبة & متوسط الانحراف & درجات الحرية & مجموع مربع & مصدر التباين \\
\hline \multirow[t]{3}{*}{$\cdot, 71$} & \multirow[t]{3}{*}{$\cdots 9$. } & . ү^.. & r &. .07 & بين المجموعات \\
\hline & &...+1 & $\varepsilon r q$ & & د/خل المجبوعات \\
\hline & & & $\varepsilon \varepsilon 1$ & & المجموع \\
\hline
\end{tabular}

يوضح الجدول (؟) السابق عدم وجود فروق دالة إحصائياً في مستوى تقديرات أفراد الدراسة لاستخدام المعلمين لأساليب تتمية

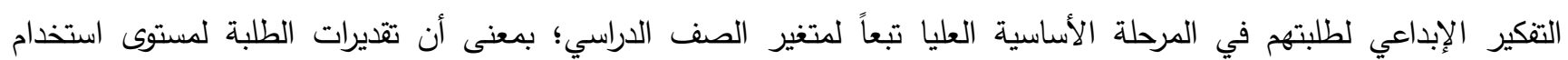
المعلمين لأساليب التنكير الإبداعي لا تختلف باختلاف الصف الدراسي. ويعزو الباحث ذلك إلى أن معلمي الصفوف في المرحلة

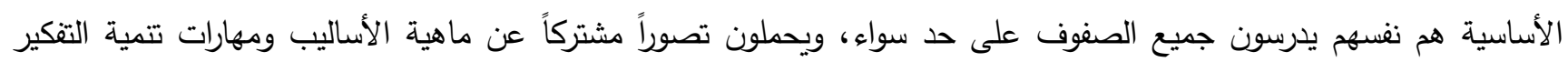
الإبداعي، مما أدى إلى وجود موقف موحد نحو تتمية مهارات التفكير وكيفية تشجيعها لاى الطلبة فجاءت تقديراتهم متقاربة. وقد يعود

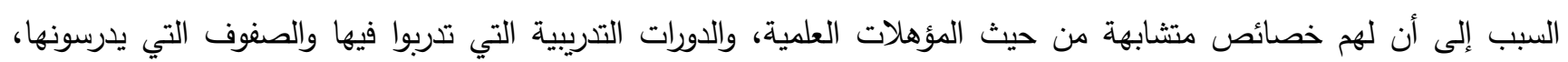

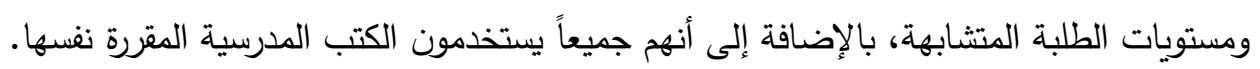
رابعاً: النتائج المتعلقة بالسؤال الرابع وهو: هل توجد فروق دالة إحصائياً في مستوى استخدام معلمي المرحلة الأساسية العليا لأساليب تنمية التفكير الإبداعي من وجهة نظر الطلبة في المدارس الحكومية بمحافظة طولكرم تبعاً لمتغير مستوى التحصيل

للإجابة عن هذا السؤال حسبت المتوسطات الحسابية والانحرافات المعيارية لمستوى تقديرات أفراد الدراسة لاستخدام المعلمين لأساليب تتمية التقكير الإبداعي لطلبتهم في المرحلة الأساسية العليا تبعاً لمتغير التحصيل الدراسي فكانت كما هو مبين في

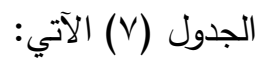

الجدول (V): المتوسطات الحسابية والانحرافات المعيارية لتقديرات الطلبة لمستوى استخدام المعلمين لأساليب تنمية التفكير الإبداعي

\begin{tabular}{|c|c|c|}
\hline الانحراف المعياري & المتوسط الحسابي & الصف \\
\hline. .01 & $r .70$ & منخفض (أقل · \% \%) \\
\hline .7 & r.Ar & 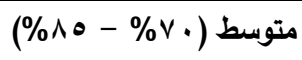 \\
\hline$\cdot .00$ & $97, r$ & مرتفع (أكثر ه^\%) \\
\hline$\cdot, \varepsilon$ & $r, v ч$ & الكلي \\
\hline
\end{tabular}

يظهر الجدول (V) السابق وجود فروق ظاهرة في المتوسطات الحسابية لتقديرات تقديرات أفراد الدراسة لاستخدام المعلمين لأساليب تتمية التفكير الإبداعي لطلبتهم في المرحلة الأساسية العليا تبعاً لمتغير التحصيل الدراسي، ولمعرفة دلالة الفروق بين هذه فئه المتوسطات الحسابية استخدم اختبار تحليل التباين الأحادي والمبينة نتائجه في الجدول (^) الآتي: 
جدول (^): نتائج تحليل التباين الأحادي لتقديرات الطلبة لاستخدام المعلمين لأساليب تنمية التفكير الإبداعي لطلبتهم تبعاً لمتفير التحصيل

\begin{tabular}{|c|c|c|c|c|c|}
\hline \multicolumn{6}{|c|}{ الاراسي } \\
\hline مستوى الدلالة & ف المحسوبة & متوسط الانحراف & درجات الحرية & مجموع مربع & مصدر التباين \\
\hline \multirow[t]{3}{*}{$\cdot, 7)$} & \multirow[t]{3}{*}{$\cdot$, , 0} & ., . Tr & r & . . $\leqslant 0$ & بين المجموعات \\
\hline & & ...r. & $\varepsilon r q$ & $1 \leqslant, Y 0 \leqslant$ & داخل المجمو عات \\
\hline & & & «1 & $1 \leqslant . r 99$ & المجموع \\
\hline
\end{tabular}

يوضح الجدول (^) السابق عدم وجود فروق دالة إحصائياً في مستوى تقديرات أفراد الدراسة لاستخدام المعلمين لأساليب تتمية

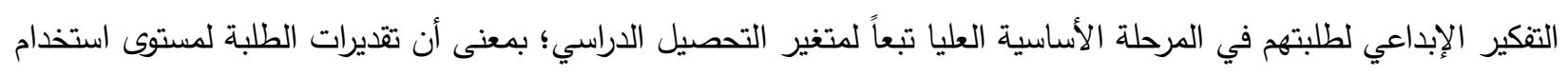

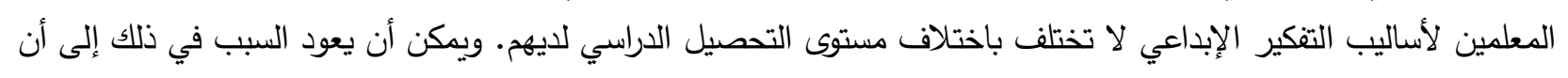

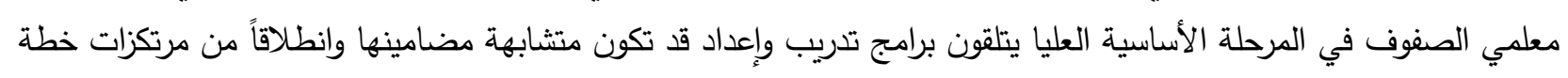

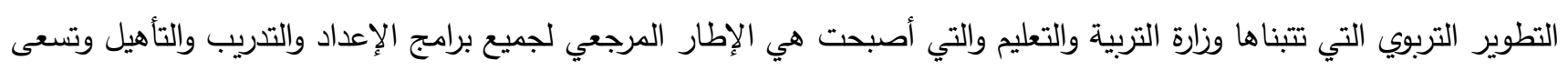

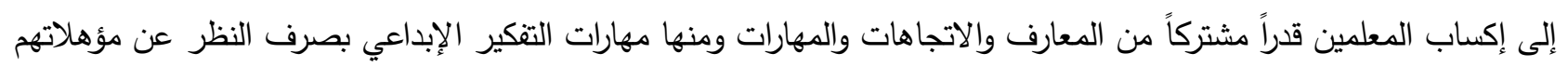
فجاءت تقديراتهم متشابهة، بالإضافة إلى أن الإعداد الأكاديمي لمعلمي لهذه الصفوف لهندان متشابهة في خططه الدراسية إذ يعين للتدريس

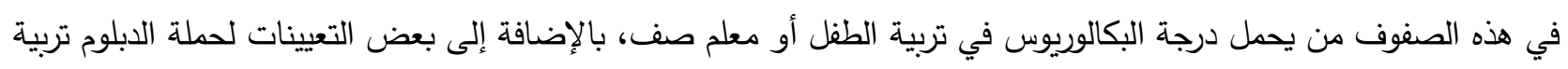
الطفل أو التربية الأساسية، وخطط هذه التخصصات تحتوي على بعض المواد التي لها علاقة بتعلم التفكير . خامساً: النتائج المتعلقة بالسؤال الخامس وهو: هل توجد فروق دالة إحصائياً في مستوى استخدام معلمي المرحلة الأساسية العليا لأساليب تنمية التفكير الإبداعي من وجهة نظر الطلبة في المدارس الحكومية بمحافظة طولكرم تبعاً لمتغير مكان السكن؟

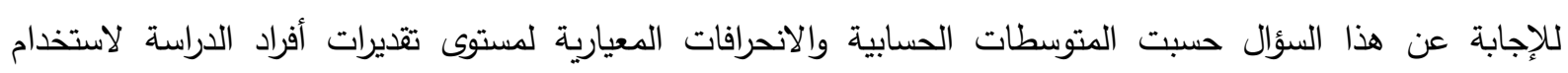

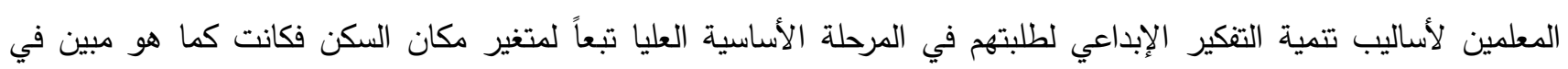

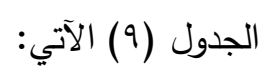

الجدول (9): المتوسطات الحسابية والانحرافات المعيارية لتقديرات الطلبة لمستوى استخدام المعلمين لأساليب تنمية التفكير الإبداعي لطلبتهم تبعاً لمتغير مكان السكن

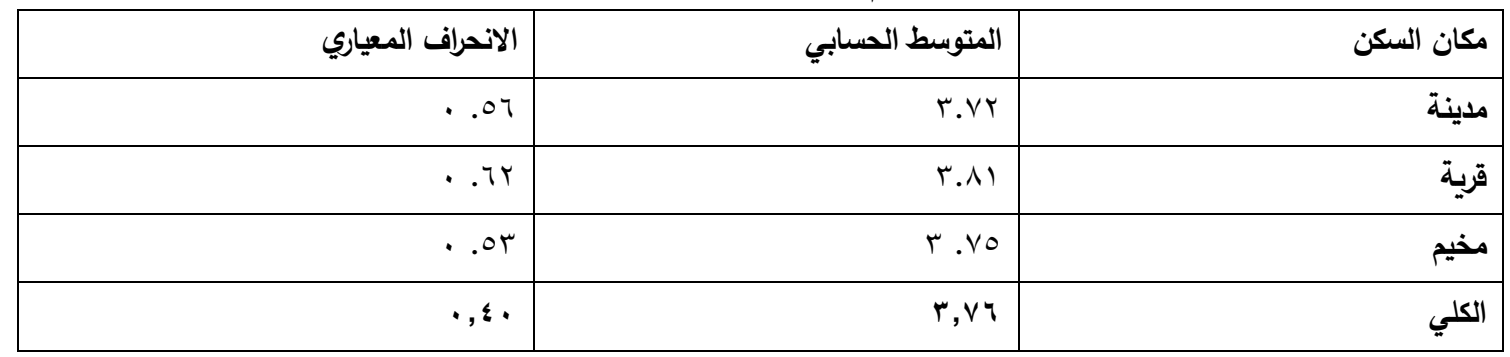

يظهر الجدول (9) السابق وجود فروق ظاهرة في المتوسطات الحسابية لتقديرات تقديرات أفراد الدراسة لاستخدام المعلمين

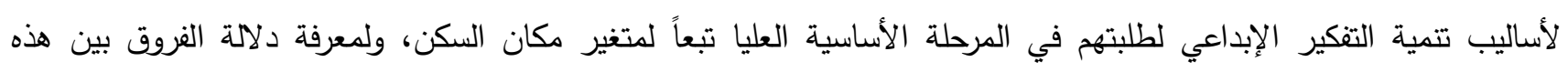

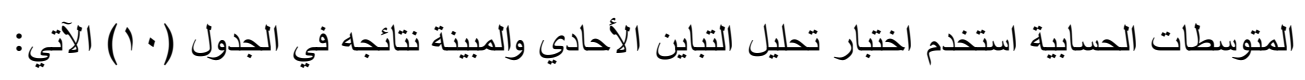


جدول (• 1): نتائج تحليل التباين الأحادي لتقديرات الطلبة لاستخدام المعلمين لأساليب تنمية التفكير الإبداعي لطلبتهم تبعاً لمتغير مكان السكن

\begin{tabular}{|c|c|c|c|c|c|}
\hline مستوى اللالالة & ف المحسوبة & متوسط الانحراف & درجات الحرية & مجموع مربع & مصدر التباين \\
\hline \multirow[t]{3}{*}{., .9} & \multirow[t]{3}{*}{ 1, vo } & $\cdot, \cdot, \leqslant 7$ & r & $\cdot .991$ & بين المجموعات \\
\hline & &...$Y 7$ & $\varepsilon r q$ & $11 . r \cdot \Lambda$ & داخل المجموعات \\
\hline & & & $\varepsilon \leqslant 1$ & $11 . r 99$ & المجموع \\
\hline
\end{tabular}

يوضح الجدول (Y) السابق عدم وجود فروق دالة إحصائياً في مستوى تقديرات أفراد الدراسة لاستخدام المعلمين لأساليب تتمية التفكير الإبداعي لطلبتهم في المرحلة الأساسية العليا تبعاً لمتغير مكان السكن، بمعنى أن تقديرات الطلبة لمستوى استخدام المعلمين لأساليب التفكير الإبداعي لا تختلف باختلاف مكان السكن للطلبة. وتعزى النتائج إلى أن الهافف الذي تسعى إلى اليه وزارة التربية والتعليم هو تحقيق المنحى التكاملي بين الاختصاصات وذلك من خلال الدورات التي تعقدها؛ فمثلاً يتم إعطاء دورات في التدريس للمعلمين في اختصاص التربية الابتدائية تسىى أساليب ومحتوى وفي المقابل تعطى دورات أساليب تدريس لمعلمين مختصين في المواد المختلفة تسمى أساليب تربية عامة وذلك لأجل إكساب المعلمين المهارات الأساسية التي يحتاجونها أثناء ممارستهم للعملية التعليمية وتساعدهم على تتمية التنكير الإبداعي لدى طلبتهم.

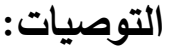
في ضوء نتائج الدراسة يمكن اقتراح التوصيات الآتية:

أولاً: فيما يتعلق بالمدرسة:

ا. توفير جو تفاعلي بين الددرسة والمجتمع المحلي من اجل تطوير معارف وقدرات وخبرات الطلبة .

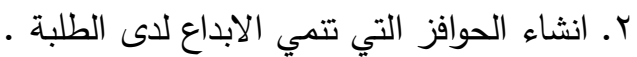

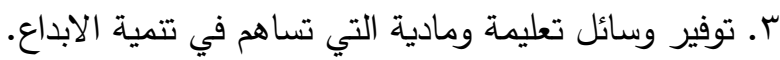

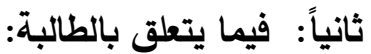

ا ـ تتمية حب الاستطلاع والمثابرة لدى الطلبة. r. تشجيع مستمر للطلبة لكي يصلوا لأعلى مراتب الإبداع. r. مشاركة الطلبة بالقرارات والنشاطات والندوات التي ترفع من مكانته العلمية والابداعية. ع. العمل على تفاعل الفرد مع البيئة واستغلالها في تتمية ابداعه.

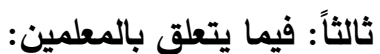

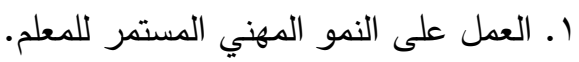
r. ان يكون هناك مشاركة فعالة للمعلم في رسم السياسة التعليمية وقوانينها. r. ان يكون هناك تحفيز للمعلمين من اجل تتمية قدراتهم الابداعية. 
ا. إبراهيم، عبد الستار (1985). آفاق جديدة في دراسة الإبداع. الكويت: وكالة المطبوعات. r. أبو عجمية، محمد (2004). واقع منهاج اللغة العربية للصف الثامن الأساسي في تتمية التفكير الابتكاري لاى الطلبة في منطقة جنوب الضفة. رسالة ماجستير غير منشورة، جامعة القدس، فلسطين. ז. جامعة القدس المفتوحة (2007). التفكير الإبداعي. منشورات جامعة القدس المفتوحة، المكتبة الوطنية. فلسطين. ع. جروان، فتحي عبد الرحمن ( 2003). الإبداع، مفهومة، معياره، مكوناتة، نظرياته. القاهرة: دار الفكر . ه. حبيب، عبد السلام (1996). رعاية الطلاب الموهوبين. عمان: وكالة المطبوعات، الأردن.

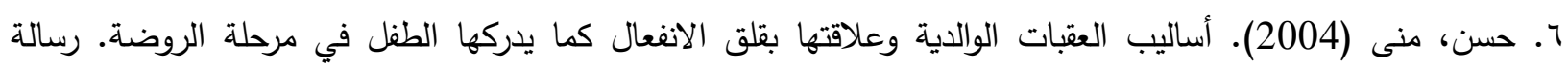
ماجستير غير منشورة، جامعة اليرموك، اربد.

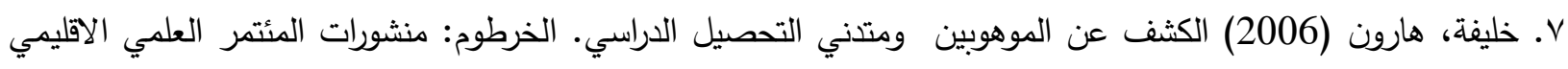
للموهبة. ^. درويش، زين العابدين (1983). تتمية الإبداع. القاهرة: دار المعارف. 9 . سعادة، طارق (2003) الطفل الفلسطيني الموهوب في محافظة رام الله. رام الله: مركز اعلام الطفل. • ا ـ صبحي، تيسير • وقطامي، يوسف (1992). مقدمة في الموهبة والإبداع. عمان: المؤسسة العربية للدراسات والنشر . ا ا ـ عاقل، فاخر (1983). الإبداع وتربيته. بيروت: دار العلم للملايين.

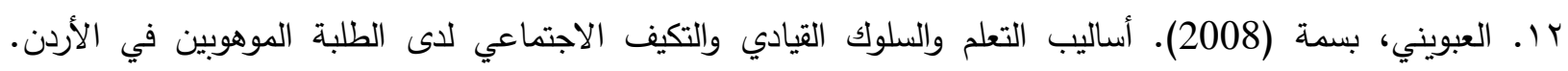
أطروحة دكتوراه غير منشورة، جامعة عمّان العربية للدراسات العليا، المملكة الأردنية الهاشمية.

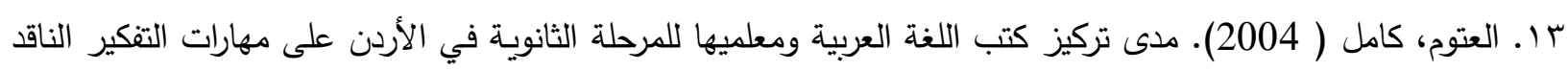
والإبداعي. رسالة دكتوراه غير منشورة، الجامعة الأردنية، الأردن.

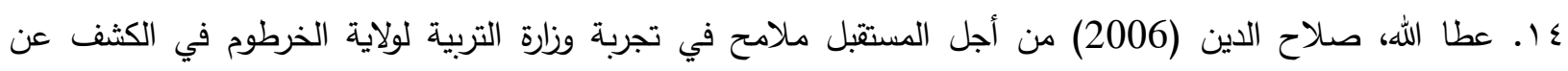
الاطفال الموهوبين. خرطوم: جامعة الملك سعود. 10. العقيل، محمد، والثايع، فهد، والجغيمان، عبدالله (2012). أثر استخدام أنثطة علمية إثرائية مقترحة في تتمية التفكير

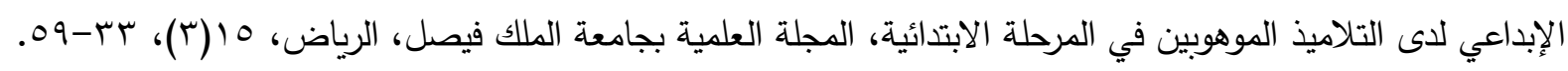
7 الـ العيسوي، عبد الرحمن (1995) سيكولوجية الإبداع دراسة في تتمية السمات الإبداعية. بيروت، لبنان: دار النهضة العربية للنشر . V ا. اللميع، فها خلف والعجمي. حمد (2010). اثر التعليم التعاوني في تتمية القدرة على التفكير الإبداعي عند طلبة

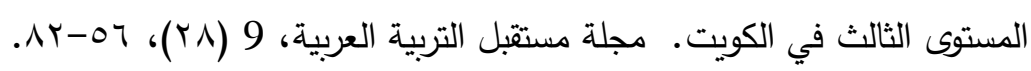
1) إ. القذافي، رمضان (2002) رعاية الموهوبين المبدعين. الاسكندرية: المكتبة الجامعية.

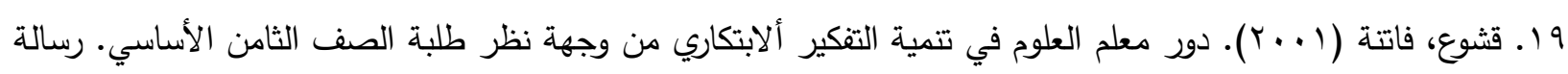
ماجستير غير منشورة، جامعة بيرزيت، فلسطين. • r. نشواتي، عبد المجيد (1985). الابتكار وعلاقته بالذكاء والتحصيل. المجلة العربية للعلوم الإنسانية، جامعة الكويت، $. \vee \wedge-\varepsilon \varepsilon ،(1 \wedge) 0$ 
[1] C. Carling, (2015). Be as Creative as You Like but Don’t Rock the Boat. Training Journal, 14 (16), 12- 14.

[2] F. Daniel, (2001). Education and Creativity. Creativity Research Journal,13(4), 317-327.

[3] R. Fobes, (2001). Creative problem solving: Futurist, ,30 (1) , 19-23.

[4] S . Gerjovch, \& M. Wright, (1988) The relationship between the general philosophy of education held by elementary school teachers and their attitudes toward creative instruction. Dissertation Abstract International, -A 48 (7), 1653.

[5] J. Guilford, (1997). Creative Talents: Their Nature Uses and Development. Buffal, New York: Bearly Cimited.

[6] M. Higgins, \& J. Morgan, (2014) .The Role of Creativity in Planning: The 'Creative Practitioner 'Planning Practice \& Research,-Feb- May2000,.15 (1/2), 117.

[7] D. Hopkinsons, (2009). Creativity in cooperative group setting. Journal of Research in Science Teaching, 22(1), 89-98.

[8] J. Horng, (2005). Creative Teachers and Creative Teaching Strategies. International Journal of Consumer Studies, 29(4), 352-358.

[9] L. Kellmer, (2007). The education of gifted children. London Press, http:www.zajel.edu.ps/articles/artc-det.aspxald=21

[10]K. Mathers, (2001). Why Study Creativity. www.bafflostate.edue/center/ creativity/ Resources/ Reading- Room/ Directory- cps.html (30/7/ 2010) .

[11]R. Narramore, (2011). Pricturing learning teacher research in words and images. Dissertation Abstracts, 53(11), 2827-A.

[12] J. Onosko, (2014). Comparing teachers' instruction to promote student thinking. Journal of Curriculum Studies, 22 (5),pp 443-461.

[13]D. Strom, \& Strom, S. (2016). Changing the rules: education for creative thinking. The Journal of creative behavior, 36 (3), 183-199.

[14]S. Suk \& M. Sideny (2006). A study of well-being and school satisfaction among academically talented students attending a Science High School in Korea. Gifted Child Quarterly, 50(2), 169-184.

[15]M. Swiatek, (2005). An empirical investigation of the social coping strategies used gifted adolescents. Gifted Child Quarterly, 23(3), 291-297. 


\title{
The Degree of Using Creative Thinking by the High Basic Teachers from the Perspective of Public Schools Students in the District of Tulkarem
}

\author{
Zeiad Barakat \\ Prof. of Educational Psychology- Educational Sciences Faculty \\ Al-Quds Open University- Palestine \\ zbarakat@qou.edu
}

\begin{abstract}
This study aimed to investigate the degree of using creative thinking by the high basic teachers frm the perspective of public schools students in the district of Tulkarem, to achieve the purposes of the study was designed questionnaire to measure the effectiveness of the teacher to use the methods in the development of creative thinking among students and consists of (34) items, each of which refers to a particular style of creative thinking development methods, and after verification of the psychometric properties of this questionnaire (validity and reliability) have been applied to a sample of students in the upper elementary size was (442) students, were selected members randomly stratified according to the variables of sex and grade The study showed the following results:

1. The estimates for the use of students graduate teachers in the basic phase of the methods of creative thinking in the public schools of Tulkarem governorate generally high level of development (3.76).

2. The lack of statistically significant differences in the level of the teachers use the upper stage of the basic techniques of creative thinking from the perspective of students in public schools Tulkarem governorate depending on variables: gender development, academic achievement, grade, and place of residence.

In light of the results of the study and discussion of proposed several recommendations, the most important: the provision of training programs for teachers to help them to adopt innovative methods to deal with the creators of students, and further studies on the development of creative thinking among students of different perspectives to deepen the results.
\end{abstract}

